\title{
Design and Management of Innovation Laboratories: Towards a Performance Assessment Tool
}

\author{
Ferney Osorio ${ }^{1,2}$, Laurent Dupont ${ }^{1}$, Mauricio Camargo ${ }^{1}$, Pedro Palominos ${ }^{3}$, José Ismael Peña ${ }^{2}$, \\ Miguel Alfaro ${ }^{3}$ \\ ${ }^{1}$ ERPI - Equipe de Recherche sur les Processus Innovatifs, Université de Lorraine Nancy, France \\ ${ }^{2}$ GISTIC - Grupo de Investigación en Sistemas y TIC en las Organizaciones, Universidad Nacional de \\ Colombia Bogotá, Colombia \\ ${ }^{3}$ Department of Industrial Engineering and Smartcity-Lab, Universidad de Santiago de Chile, Chile
}

\begin{abstract}
There is a strong emergence of new spaces to foster innovation all over the world (Fablabs, Living Labs and Design Factories, among others). Past experiences have shown these types of projects involving "innovation laboratories" are at risk of not succeeding in their goals. Although several studies have tackled the problem of design, development and sustainability of innovation laboratories, there is still a gap in understanding how the capabilities and performance of these environments are affected by the strategic intentions at the early stages of design and functioning. Throughout this work, eight frameworks from the literature that analyse innovation laboratories are identified and compared. Then, based on both literature and the authors' experience, an updated framework is proposed as the basis for a guidance tool for researchers and practitioners aiming to assess or to adapt an existing project. As part of the operationalisation process of the framework, a maturity grid-based assessment tool is proposed to evaluate the maturity degree of an innovation laboratory. Afterwards, to evaluate the viability and to integrate the perception of innovation laboratory managers, an exploratory study with answers from fifteen laboratories from five different countries is performed. Insights and implications for emerging and already existent projects of innovation laboratories are then discussed.
\end{abstract}

Keywords: innovation laboratory, strategy, physical spaces, maturity assessment

\section{INTRODUCTION}

Organisations are increasingly interested in creating dedicated physical spaces to foster innovation processes. For more than ten years, universities, research institutes, incubators, accelerators, innovation centres, co-working spaces, start-up spaces and more have grown at a considerable pace across the globe (Wagner \& Watch, 2017). Depending on the context, these physical environments can take the form of laboratories with different kinds of spaces, such as creativity and prototyping rooms, co-workings spaces, testing rooms, immersive rooms etc. According to the literature, an "innovation laboratory" is a room or set of rooms designed for spatial re-configuration, participant observation (Griffin \& Michele Kacmar, 1991), writing spaces, materials for visualisation (post-it notes, paper, pens, cards) and information and communications technologies (ICT) to support brainstorming and distributed group working (Nunamaker, Applegate, \& Konsynski, 1988).

Looking for a more integral definition, an innovation laboratory can be described as a facility for encouraging creative behaviours and supporting innovative projects through the provision of appropriate resources, visualisation and prototyping facilities, and the ability to reconfigure new projects (Lewis \& Moultrie, 2005; Moultrie, Nilsson, et al., 2007). These laboratories shall increase the capability of new product development and decrease time to market and are usually aligned with the firm's or organisation's strategic intention and scope (Gey, Meyer, \& Thieme, 2013; Villani, Rasmussen, \& Grimaldi, 2017).

Contact author: fosoriob@unal.edu.co 
Besides recent definitions of innovation laboratories, understanding how these physical spaces contribute to innovation has been a topic of concern for years. Snead \& Wycoff (1999) worked on the development of creativity rooms as an input to innovation, whilst Kristensen (2004) proposed wider implications of how workspace design influences innovation. Also, Lewis \& Moultrie (2005) condensed and proposed the innovation laboratory concept, and Dupont (2009) designed a prototype for an environment to boost collaborative processes. More recently, studies like those performed by Andersson Schaeffer \& Eriksson (2014), or even the one by Shirahada \& Hamazaki (2013), have started to focus on how physical spaces influence the culture in a workplace within an ambidextrous organisation. In that sense, Mortara \& Parisot (2018), through a survey of 12 case studies of individual entrepreneurs in the USA, UK and France, analyse how spaces specifically designed to provide access to a wide range of manufacturing equipment are currently encouraging the distribution of innovation across society.

In that regard, the concept of innovation space has emerged as an alternative to innovation laboratories, specifically to acknowledge how these physical environments provide opportunities to (1) engage with people, ideas and technologies; (2) experience participatory culture; and (3) acquire the literacy and skills needed to prosper in the 21st century (Prefontaine, 2012). Based on this, Stercken (2015) identified that innovation spaces can generate economic capital results but also there are impacts on users' social, intellectual and psychological capabilities. Therefore, according to Wagner \& Watch (2017), spaces that have achieved a certain level of prominence have done so by aligning organisational ambition, culture and people to produce a supportive, enabling design.

In the same way, when referring to innovation laboratories it is necessary to think about how this physical space encourages creative behaviour for the people within it, not just referring to them as customers and employees, but as users. According to Lewis \& Moultrie (2005), one of the main objectives when designing an innovation laboratory is to consider the fact that the users need to be in a space that reduces the hierarchy and supports participation. The physical design of the space should promote dynamism, playfulness and debate in order to achieve those three desirable characteristics for a creative climate (Ekvall, 1997). This is a step closer to the democratisation of innovation, where all users are elevated and empowered to articulate how a space should be moulded to support their needs and ambitions (Wagner \& Watch, 2017).

Nonetheless, it is important to notice the more complex, multi-directional and networked nature of how innovation takes place in laboratories (Gryszkiewicz, Lykourentzou, \& Toivonen, 2016). Consequently, managers of innovation laboratories face a challenge that goes beyond just managing them. Peschl \& Fundneider (2014) suggest that innovation needs to be enabled rather than controlled. More concretely, they state that, to manage an innovation space, managers have to "learn how to provide an ecosystem of living ambiances of cultivation, facilitation, incubation and enabling, rather than a regimen of control and forced change" and to consider both physical space and organisational climate as part of the enabling context (Peschl \& Fundneider, 2012).

Despite the previous work, there is still a gap in understanding what the actual capabilities of innovation laboratories are and the degree of expertise in which their practices and processes are determined. Therefore, in this article, we focus on identifying which criteria are useful to examine in order to understand what the common practices among laboratories are. Our objective is to propose a method to evaluate the outcomes of innovation laboratories, looking to provide tools for strategically designing and conceiving spaces to support innovation processes. To achieve that, eight frameworks are identified and compared, whereby Moultrie's is selected as the most comprehensive and suitable for the objective of this research. From there, we present an updated framework as the basis for the construction of a maturity grid-based assessment tool whose first version is finally tested in an exploratory study among managers of 15 different innovation laboratories around the world. 
In the following, the methodological approach is presented in which the main stages of our research process are described. Next, based on an exploratory study, an adjusted framework is proposed, followed by the first version of a strategy-oriented maturity grid and finally the design of the assessment tool (questionnaire). Then, the main empirical results of its application to a group of international innovation laboratories are discussed. At last, a discussion of the validation and its practical implications is addressed, before proposing a conclusion and further steps of this research.

\section{METHODOLOGICAL APPROACH}

The research in this study is exploratory in nature and aims to foster an understanding of the phenomena under investigation rather than testing pre-existing hypotheses. It is therefore based on the authors' experience and the collaboration between both universities and two of their laboratories. These are the Lorraine Fab Living Lab ${ }^{\circledR}$ platform (connected to the Lorraine Smart Cities Living Lab project) of the Universite de Lorraine in France and the ViveLab Bogotá of the Universidad Nacional de Colombia. With five and two years of operation respectively, common issues have been shared and identified, giving place to the questions that motivate this research. This research was conducted through a five-stage process, as shown in Figure 1.

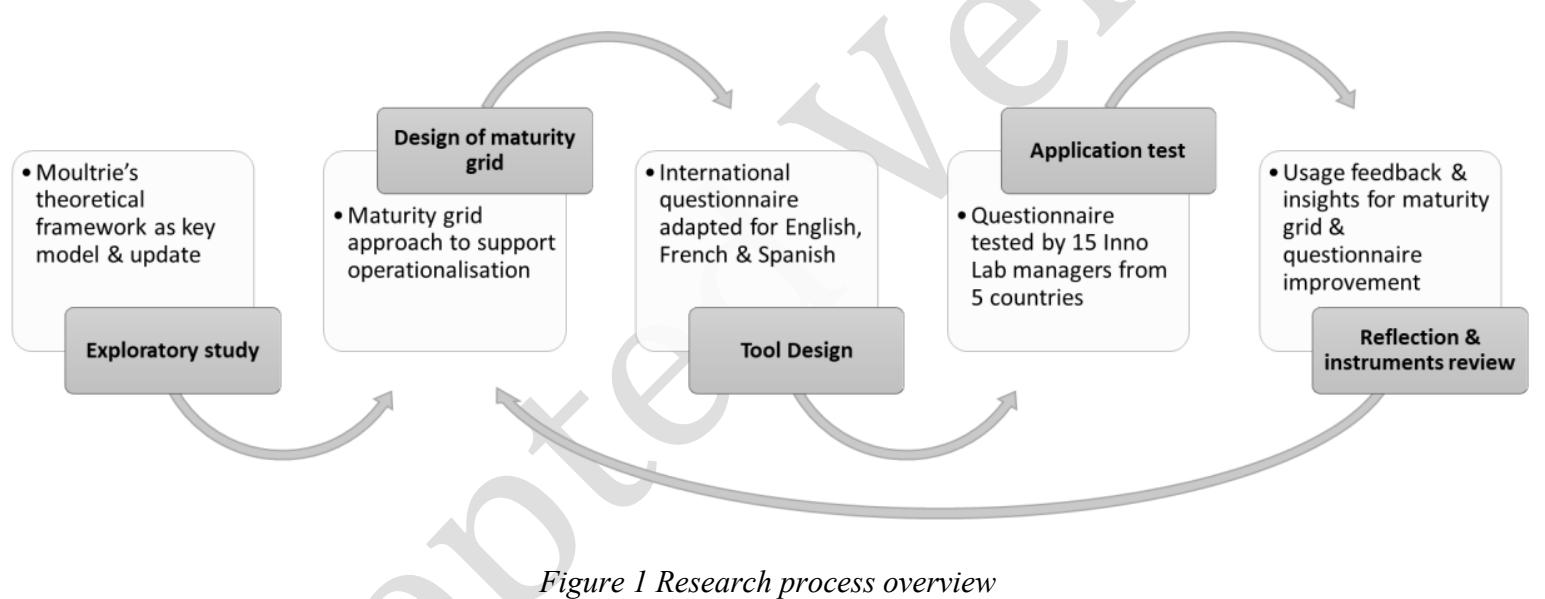

In the literature review, eight frameworks were already selected due to their comprehensiveness, giving relevance to both strategic and spatial aspects as part of the laboratory. Next, a comparison between the eight frameworks was performed, remarking on the positive aspects or the disadvantages of each of them. As none of the frameworks seemed to be totally oriented towards the objective of this research, and some of them remain theoretical works, we attempt to propose a conceptual framework adjusted to the conditions of this research. From there, we aim to operationalise the updated framework by building a maturity grid and designing a collection tool. Based on this, a maturity grid-based assessment tool for innovation laboratories could be validated.

As innovation laboratories are exposed to deal with substantial financial matters and possibly short useful lifespans (Lewis \& Moultrie, 2005), their challenge is to adapt rapidly without losing their thematic focus and continuously share and align their strategic intention with all the stakeholders (Veeckman, Schuurman, Leminen, \& Westerlund, 2013). This has led to significant diversity in laboratories, managing practices and unpredictable outcomes. Thus, the idea of capturing good practical knowledge through a process maturity approach to support improvements initiatives, as applied by Moultrie, Clarkson \& Probert (2007), appears to match in this case.

Due to the exploratory nature of this research, we opted for building a maturity grid as an alternative 
to capturing practices and outcomes of innovation laboratories. A collection tool was designed to include directors and managers from laboratories in this process. Then, an international survey is performed among 15 innovation laboratories as an application test from which insights and usage feedback are collected and discussed. Finally, this analysis will be used to strengthen the maturity grid as well as to improve the questionnaire.

\section{EXPLORATORY STUDY}

\section{Comparison of existing frameworks on physical environments for innovation}

Table 1 summarises the eight frameworks identified in the literature. Here, we show the main features, as well as the differences between them based on five comparison dimensions. It is important to note that some frameworks comprise a more detailed level of elements by disaggregating specific components for certain constitutive pillars. However, not all of them reach that level of specificity; we therefore only present the main pillars. Regarding the comparison, we established a set of five dimensions to identify the comprehensiveness of the current frameworks (Osorio Bustamante, Pena Reyes, Camargo, \& Dupont, 2015). These dimensions are:

- Space \& infrastructure focus: As the motivation and research questions rely on the role of the physical space to support innovation, we try to compare whether the space or the infrastructure has been considered as one of the main features of analysis.

- Strategy vs. outcomes approach: To understand the performance of the space it is necessary to analyse how and why it was initially conceived, and the way the space has been used; we therefore seek to identify a framework that contributes in this regard.

- Criteria definition: Almost all frameworks have a solid theoretical basis, although not all of them define criteria to evaluate their constitutive pillars. Those with a criteria definition are considered a significant input.

- Operationalisation \& metrics: In addition to the criteria, we look at whether instruments and metrics were developed for each framework.

- Case study: Finally, we compare which frameworks have been tested and deployed through single- or multi-case studies.

Throughout this section, the identified frameworks will be discussed and the main features and the context in which they were developed will be underlined.

The first framework (Moultrie, Nilsson, et al., 2007) recognises that the environment itself can be part of the organisation's innovation strategy (rather than ad hoc) and can influence performance in innovation. Consequently, "if resources are going to be invested in the creation of an innovation environment, then it is essential that strategic intentions underpinning this space are explicit" (Moultrie, Nilsson, et al., 2007). A remarkable point of view taken by them is the outcome approach. They used the transformation model (progression from inputs to outputs) (Woodman, Sawyer, \& Griffin, 1993) as the conceptual foundation to consider how strategic intent may be transformed into specific innovation environments and how these are subsequently used to deliver new products and services. In addition, they did a specific study of what the physical embodiment of such spaces should be. These elements seem to be a useful tool to examine and compare which kinds of real environments are implemented in different laboratories. In that sense, this framework is comprehensive and detailed, and identifies which elements are involved for each block or process. Although the framework was never operationalised, it is a significant input to advance in this research.

Subsequently, Dupont (2009) presents a physical environment specifically designed to facilitate collaborative work. The author proposes a coherent framework to enable the involvement of the end 
users at the early stage of an urban project. He highlights that the key pillars of the framework are the involvement of various stakeholders, the attitude towards collaboration and a structured process. Then, those pillars shall be embedded in a customised space to accelerate such a process from the sharing of stakeholders' requests to a reached consensus. This framework has been deployed, tested and analysed (Dupont, Morel, Hubert, \& Guidat, 2014; Skiba, 2014; Skiba, Dupont, Morel, \& Guidat, 2012) through the Lorraine Smart Cities Living Lab project. Furthermore, the Lorraine Fab Living Lab platform gives the opportunity for new developments and experiments (Dupont, Guidat, Morel, \& Skiba, 2016; Dupont, Morel, \& Lhoste, 2015). Still, identified points for improvement remain its reproducibility and the definition of key performance indicators to measure the steps of the process and its outcomes.

Afterwards, Gey et al. (2013) introduced a conceptual framework for the analysis of innovation laboratories based on structuration theory and a meta-structuring approach proposed by Orlikowski, Yates, Okamura \& Fujimoto (1995). They show the influences of different actors (designers, operators and users) on the design and usage of the innovation laboratories. This is presented through eight categories based on roles and tasks which help to define multiple meta-structuring activities to support the operation of a laboratory. While this framework can help compare and characterise different laboratories, this is mainly at an operational level with no associated metrics and without considering strategic relationships.

Schuurman et al. (2013) proposed a framework for "infrastructure driven laboratories" with the Living Labs domain. Their proposal is based on the experience with the LeYLab, which basically offered fibre-optic Internet access to a panel of 115 households and organisations to stimulate innovation on media and eHealth. After years of operation, they realised that a heavily infrastructuredriven laboratory imposes some risks, such as the roll-out, which can take longer, and the integration of the external cases into the original intent. All the external cases they had were situated in the media domain, whereas no further eHealth cases were held. This shows the need for a clear thematic focus for a laboratory to easily define which projects it attracts and realises. The framework proposes that the infrastructure represent the core of the laboratory and the other five general elements depend on this infrastructure.

Table 1. Comparison of frameworks

\begin{tabular}{|c|c|c|c|c|c|c|c|}
\hline \multicolumn{3}{|c|}{ State of the art } & \multicolumn{5}{|c|}{ Set of five dimensions } \\
\hline Author & Description & Constitutive pillars & 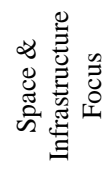 & 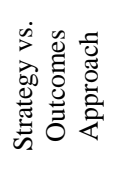 & 䄈: 总 & 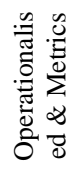 & 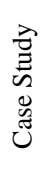 \\
\hline $\begin{array}{c}\text { Moultrie, } \\
2007\end{array}$ & $\begin{array}{l}\text { Role of physical } \\
\text { environment in } \\
\text { Innovation }\end{array}$ & $\begin{array}{ll}- & \text { Strategic intent } \\
- & \text { Process of creation } \\
- & \text { Physical space } \\
- & \text { Process of use } \\
- & \text { Realised intent }\end{array}$ & $\mathbf{X}$ & $\mathbf{X}$ & $\mathbf{X}$ & & \\
\hline $\begin{array}{c}\text { Dupont, } \\
2009\end{array}$ & $\begin{array}{c}\text { EMA space - } \\
\text { environments to } \\
\text { foster collaborative } \\
\text { innovation }\end{array}$ & $\begin{array}{ll}- & \text { Governance \& stakeholders } \\
- & \text { Collaborative methodologies } \\
- & \text { Change management process } \\
- & \text { Technology (equipment \& } \\
\text { methods) }\end{array}$ & $\mathbf{X}$ & & $\mathbf{X}$ & & $\mathbf{X}$ \\
\hline Gey, 2013 & $\begin{array}{l}\text { Framework for } \\
\text { describing the } \\
\text { innovation } \\
\text { laboratory } \\
\text { phenomenon }\end{array}$ & $\begin{array}{ll}- & \text { Actor of innovation } \\
- & \text { Methods - Designer } \\
- & \text { Actions at interface between } \\
& \text { operator and lab } \\
- & \text { Operators } \\
- & \text { Actions of operator } \\
- & \text { Operations } \\
- & \text { User }\end{array}$ & $\mathrm{X}$ & & $\mathbf{X}$ & & \\
\hline
\end{tabular}


Published in Journal of Creativity and Innovation Management - Volume 28:82-100 March 2019

DOI: https://doi.org/10.1111/caim.12301

\begin{tabular}{|c|c|c|c|c|c|c|}
\hline & & - $\quad$ Idea of innovations & & & & \\
\hline $\begin{array}{l}\text { Schuurman, } \\
2013\end{array}$ & $\begin{array}{l}\text { Living Lab } \\
\text { constellation }\end{array}$ & $\begin{array}{ll}- & \text { Infrastructure } \\
- & \text { Natural setting } \\
- & \text { Multi-method } \\
- & \text { Medium- to long-term } \\
- & \text { User-centric } \\
- & \text { Multi-stakeholder }\end{array}$ & $\mathbf{X}$ & & & $\mathbf{X}$ \\
\hline $\begin{array}{l}\text { Veeckman, } \\
2013\end{array}$ & $\begin{array}{l}\text { The Living Lab } \\
\text { triangle }\end{array}$ & $\begin{array}{ll}- & \text { Innovation outcome } \\
- & \text { Technical infrastructure } \\
- & \text { Ecosystem approach } \\
- & \text { Level of openness } \\
- & \text { Community } \\
- & \text { Lifespan } \\
- & \text { Real-world context } \\
- & \text { Evaluation } \\
- & \text { Context research } \\
- & \text { Co-creation } \\
- & \text { User role } \\
\end{array}$ & & & $\mathbf{X}$ & $\mathbf{X}$ \\
\hline $\begin{array}{l}\text { Peschl, } \\
2014\end{array}$ & $\begin{array}{l}\text { Enabling spaces } \\
\text { framework }\end{array}$ & $\begin{array}{ll}- & \text { Architectural and physical } \\
\text { - } & \text { Space } \\
& \text { Social, cultural and } \\
\text { - } & \text { organisational space } \\
- & \text { Cognitive space } \\
- & \text { Emotional space } \\
- & \text { Epistemological space } \\
& \text { Technological and virtual space }\end{array}$ & $\mathbf{X}$ & & & $\mathbf{X}$ \\
\hline Kallio, 2015 & $\begin{array}{l}\text { The triangle of } \\
\text { physical space, } \\
\text { organisational } \\
\text { culture and } \\
\text { organisational } \\
\text { creativity }\end{array}$ & $\begin{array}{ll}- & \text { Location } \\
- & \text { Spatial organisation } \\
- & \text { Architectonic details } \\
- & \text { Openness } \\
- & \text { Collectivity } \\
- & \text { Equality } \\
- & \text { Organisational creativity }\end{array}$ & $\mathbf{X}$ & & & $\mathbf{X}$ \\
\hline $\begin{array}{l}\text { Klooker, } \\
2015\end{array}$ & $\begin{array}{l}\text { 3-dimensional } \\
\text { model (facilitator, } \\
\text { provide and } \\
\text { communicator) }\end{array}$ & $\begin{array}{ll}- & \text { Work modes } \\
- & \text { Mindset } \\
- & \text { Collaboration } \\
- & \text { Interaction } \\
- & \text { Initiative } \\
- & \text { Product development } \\
- & \text { Place } \\
- & \text { Equipment } \\
- & \text { Advanced technical devices } \\
- & \text { Space } \\
- & \text { Curriculum } \\
- & \text { Experience } \\
- & \text { Motivation } \\
- & \text { Identity } \\
\end{array}$ & $\mathbf{X}$ & $\mathbf{X}$ & $\mathbf{X}$ & $\mathbf{X}$ \\
\hline
\end{tabular}

Following this, Schuurman et al. (2013) made another significant contribution in the literature by also defining the scope of the term infrastructure. They propose that a laboratory can be composed of material infrastructure, such as all the tangible assets that are brought to the space: physical networks, user devices, research equipment. But they also consider the immaterial infrastructure, referring to all the intangible assets that surround a laboratory, such as the environment, the stakeholders and the end users. Nevertheless, this work does not go into depth about what exactly those elements are and what their contributions to the outcomes are. The Living Lab constellation of Schuurman presents an original approach based on a single-case experience at the generic level but it is also possible to think on a multi-project level by analysing each project as a unique constellation. However, this framework is still exploratory and preliminary. Nonetheless, finding out that the motivation for this research is a common interest of other authors, it validates the emergence of this issue. 
On the other hand, the Living Lab triangle is centred to find a way to measure the innovation outcomes of these laboratories. This framework is one of the most comprehensive in the literature, gathering previous concepts and elements which aim to understand the behaviour of Living Labs (Veeckman, Schuurman, Leminen, Lievens \& Westerlund, 2013). However, the infrastructure aspect is limited to technical matters and does not seem to be considered an influential factor within the framework. Despite this, as part of the conclusions further in this work, the authors realised that infrastructure actually plays a bigger role and needs to be clearly defined as part of the general strategy of the laboratory. Between the selected frameworks, the Living Lab triangle is the only one which has been operationalised to perform a multi-case analysis among four laboratories (Veeckman, Schuurman, Leminen \& Westerlund, 2013). Therefore, it represents an important reference to be considered in our path to propose our own adapted framework.

Peschl \& Fundneider (2012) have studied the term "enabling spaces" over several years. They have developed a framework based on the premise that innovation should be enabled (facilitated) rather than managed (referred to as controlling). This framework considers that an enabling space is designed as a multi-dimensional space in which architectural/physical, social, cognitive, technological, epistemological, cultural, intellectual, emotional and other factors are considered and integrated. Following this work, in (Peschl \& Fundneider, 2014) the authors state that each space has to be specifically designed for each organisation and its quality relies on carefully choosing the parameters of each space: scenic location, almost no tables, different seating scenarios including a private situation for individual thinking, as well as a more public setting for negotiating knowledge, mobile ICT infrastructure, lots of space for presentation, workshop equipment facilitating the transformation of ideas into tangible prototypes etc. The enabling spaces framework proposes an original approach that has been developed through previous research, but it is still not operationalised.

Kallio, Kallio \& Blomberg (2015) conducted a longitudinal study comparing a case organisation before and after a change in its physical environment. The longitudinal data illustrates how a change in the spatial environment contributes to the emergence of a culture conducive to organisational creativity. The study is based on an in-depth, longitudinal case study, the aim being to enhance understanding of how a change in physical space, including location, spatial organisation and architectonic details, supports cultural change. To do this, it uses a model comprising three concepts, namely: the triangle of physical space, organisational culture and organisational creativity. However, the strategic issue has not been developed in his work.

Finally, as part of the literature review, Klooker, Matzdorf, Nicolai, Boettcher, \& Trost (2015), based on the application of a 3-dimensional model for workspaces (Amabile, 1988), introduces a collection of inductive categories defining strategic intent preceding the establishment of innovation laboratories within organisations. However, the proposal is not very operable, since it is more a descriptive study than a quantitative one, which makes it difficult to compare with other spaces of innovation.

As a result of the comparison of frameworks, we summarise the main findings as follows:

- Regardless of the laboratory label, it is clear that spaces play an active role in open innovation processes and outcomes.

- In general, research efforts to understand their role and contribution remain theoretical and exploratory.

- To diagnose the performance of an innovation laboratory it is necessary to analyse how it was conceived, materialised and used.

- It is important to establish a common understanding of what composes the physical embodiment of an innovation laboratory.

- The framework can work just as a tool or guideline. Each space must be designed for each 
laboratory according to its context.

\section{Towards an updated framework}

In the previous bibliographic discussion, a close relation has been observed between the physical environment and strategic intention with innovation performance. Thus, it is possible to think that, if at the project stage of an emerging laboratory, it is possible to have a way of assessing and analysing the proper environment for intended goals, the outcomes of such an intention could be better oriented. In addition, if during that process we contribute to understanding the way that physical space and resources are used, it could be possible to establish some guidelines for those laboratories that are already in operation to redirect their strategy or to adapt the existing space.

Considering this and the results of the comparison, we believe that Moultrie, Nilsson et al. (2007) provide the most fitting framework for the purpose of this research. They comprise the process of creation of the innovation environment (physical space) to satisfy strategic goals (strategic intention), and the process by which such space is used and the degree to which the strategic goals are met (realised intention). Additionally, elements that compose each pillar and process are theoretically described. However, as addressed in the previous section, this framework was developed in a specific context. Since 2007, several societal evolutions have generated a new context and it seems relevant to improve Moultrie's framework with new incomes and knowledge:

- First, although Moultrie considers the context, it was addressed as an innovation space within a company. Today, this dimension takes even more importance because the large diffusion of innovation laboratory involving open and virtual communities, the general public etc. Hence, this type of project must be more resilient in regard to its global, regional and local context. Furthermore, such a project always makes part of a particular ecosystem (whether a university, city or industry) take into account the stakeholders' expectations and needs as well as the nature of and culture of the community that allows it to exist.

- Second, an innovation laboratory must help stakeholders connect with the reality of each other, i.e. the real-world lives of the different stakeholders, to better understand context and anticipate concrete issues. Moreover, some projects require the implementation of real-size demonstrators in the real situation of use (Dupont, Morel, \& Guidat, 2015).

- Third, innovation laboratories are open spaces where various cultures intersect. Studies (Dupont, Gabriel, Camargo, \& Guidat, 2017; Morel, Dupont, \& Boudarel, 2018) show that we can view stakeholders as a "community of interest" or "community of practices". According the stakeholders' motivation and practices, it is necessary to adapt the physical environment and the technologies.

- Also, the collaborative aspects must be integrated as these behaviours around the innovation laboratory generate profitable opportunities for innovation (Del Vecchio, Elia, Ndou, Secundo, \& Specchia, 2017; Pallot, Trousse, Senach, \& Scapin, 2010). Furthermore, the user is a specific key stakeholder for whom methods of involvement have largely been designed and implemented (Dupont et al., 2016).

In addition to updating the framework in a new context (e.g. more open, more virtually distributed etc.), there is the need to operationalise it, through a structured hierarchy and the possibility of evaluating each element of the pillars.

Figure 2 proposes an updated framework based on the experience of the projects described in literature discussion presented earlier in this work. As has been shown, establishing a clear strategic intention at the early stage of the project is fundamental, and the literature has actively evolved in that 
Published in Journal of Creativity and Innovation Management - Volume 28:82-100 March 2019

DOI: https://doi.org/10.1111/caim.12301

regard during the last few years. Among the other frameworks studied in this work, it is possible to identify common elements that define which aspects should be considered to set up the strategy for an innovation laboratory supported and shared by several stakeholders, such as companies, academics, open labs, factories etc.

To be precise, the contributions to this updated framework rely on the consideration of the previous mentioned elements, where only strategic goals and teamwork elements are retained from the original framework, as five new ones are proposed:

- Ecosystem approach: To generate added value for all the stakeholders involved, creating long-term engagement and sense of belonging with the laboratory.

- Real-world context: To capture or resemble real-life environments (through space, equipment or methodologies) and enable stakeholders to understand how others understand the context.

- User-centric innovation: To adopt a user's point of view and involve them in the different phases of the innovation cycle, in which they can test, evaluate, contribute and co-create. The user is not necessarily the direct customer. He or she can benefit from a use without having bought it directly.

- Culture and community: To build an identity and to grow a community of users or partners engaged and motivated with access to the laboratory.

- Lifespan: To estimate the length of the project as a whole (short-, medium- or long-term).

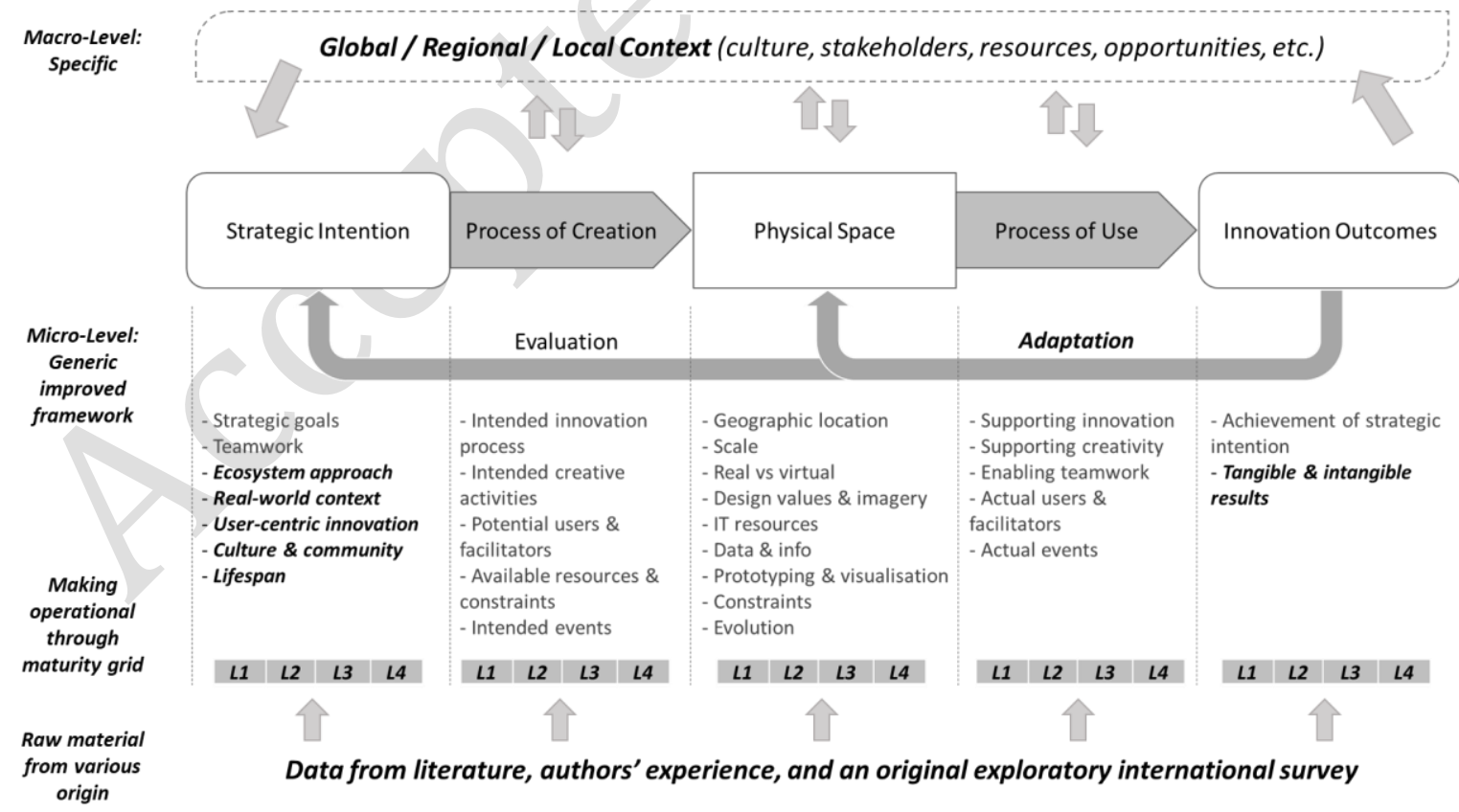

Figure 2. Updated framework based on Moultrie, Nilsson et al., 2007

Ultimately, we also believe that "realised intention" should be seen as innovation outcomes with tangible and intangible results that allow us to assess impact and determine how the laboratory

Contact author: fosoriob@unal.edu.co 
performed. With these results, decisions can be made either to make early modifications to the functioning and the space (adaptation) or to deeply address the strategic intention (evaluation).

\section{Proposition of a strategy-oriented maturity grid}

As the aim of this work is to go deep into the operationalisation of the framework, the next step in the methodology was to have a clear definition of each indicator proposed in the framework. In addition, a first approximation to a maturity grid was made based on the literature review as well as the experience of the authors and a group of experts.

Here, the concept of maturity is taken into consideration as a measure to quantify the organisational capabilities (Maier, Moultrie \& Clarkson, 2012). This concept is helpful for determining standard practices or processes, and their classification by degree of expertise (Claire, Galvez, Boly, Camargo $\&$ Moselle, 2014). One way to do this is by looking at what people are doing operationally and analysing behaviours, attitudes and competences (Maier et al., 2012). This is usually visualised in a set of cumulative stages, where higher stages build on the requirements of the lower ones. This evolution towards maturity can be made using a ladder representation (Andersen \& Jessen, 2003). These representations can vary from Likert-type scales to maturity scales with multiple anchor phrases and detailed performance descriptions (Moultrie, Clarkson et al., 2007).

In this case, the maturity grid is used as a methodological representation of our framework. Based on the definition of each criterion, we built a set of four levels of maturity using anchored phrases to describe performance at each end of the scale. Then, from Level 1 to Level 4 we have a transition from low to high performance. However, most of these levels were identified from the literature but in some cases, it was necessary to appeal to our own experience and discussions with some experts to determine the levels of maturity for certain criteria. Consequently, this maturity grid constitutes an initial version that needs to be discussed and completed based on the actual experience and actions undertaken within the innovation laboratories.

Strategic Intention: The first process to be considered is the "strategic intention". As an example, Table 2 shows the detailed maturity grid for the Strategic Intention pillar. For reasons of space, the detailed maturity grids for the rest of the blocks are shown in Appendix 1. According to Moultrie, the design of an environment "enables the development of unique capabilities, enables reconfiguration of capabilities to changing demands, and supports synergies between complementary assets" (Moultrie, Nilsson et al., 2007). Hence, it is determinant to be conscious of which kind of capabilities and assets are important to enable and how the laboratory is strategically conceived around its context.

Process of Creation: Beyond strategic reflection, it is necessary to understand the types of people who will use the space and their needs, including the degree to which independent facilitation is required and how the space will be linked to the whole innovation process. Likewise, during the "process of creation" one should be aware that, in practice, any work environment will evolve from the original intentions and will manifest the real work undertaken there. 
Published in Journal of Creativity and Innovation Management - Volume 28:82-100 March 2019

DOI: https://doi.org/10.1111/caim.12301

Table 2. Maturity grid for the Strategic Intention pillar

\begin{tabular}{|c|c|c|c|c|c|c|}
\hline Criteria & Description & Level 1 & Level 2 & Level 3 & Level 4 & Reference \\
\hline $\begin{array}{l}\text { Strategic } \\
\text { Goals }\end{array}$ & $\begin{array}{l}\text { To support } \\
\text { organisation / } \\
\text { partnership mission }\end{array}$ & $\begin{array}{l}\text { No goals } \\
\text { defined }\end{array}$ & $\begin{array}{l}\text { Short-term } \\
\text { goals. Not } \\
\text { measurable. }\end{array}$ & $\begin{array}{l}\text { Medium-term } \\
\text { goals. Clear } \\
\text { thematic goals. } \\
\text { Measurable. }\end{array}$ & $\begin{array}{l}\text { Long-term and } \\
\text { sustainability } \\
\text { goals. Measurable. }\end{array}$ & $\begin{array}{l}\text { (Moultrie et } \\
\text { al., 2007) }\end{array}$ \\
\hline $\begin{array}{l}\text { Ecosystem } \\
\text { Approach }\end{array}$ & $\begin{array}{l}\text { To generate added } \\
\text { value for all the } \\
\text { stakeholders } \\
\text { involved, creating } \\
\text { long-term } \\
\text { engagement and } \\
\text { identification with } \\
\text { the laboratory. }\end{array}$ & $\begin{array}{l}\text { No value } \\
\text { creation. No } \\
\text { sharing for } \\
\text { stakeholders. }\end{array}$ & $\begin{array}{l}\text { Partially } \\
\text { Sharing. } \\
\text { Missing links } \\
\text { between } \\
\text { stakeholders. } \\
\text { No equal } \\
\text { contribution. }\end{array}$ & $\begin{array}{l}\text { Value and } \\
\text { sharing for most } \\
\text { of the } \\
\text { stakeholders. }\end{array}$ & $\begin{array}{l}\text { Value creation and } \\
\text { sharing for all } \\
\text { stakeholders. } \\
\text { Long engagement. }\end{array}$ & $\begin{array}{l}\text { (Dupont et al., } \\
2014 ; \\
\text { Veeckman et } \\
\text { al., 2013) }\end{array}$ \\
\hline $\begin{array}{l}\text { Real-World } \\
\text { Context }\end{array}$ & $\begin{array}{l}\text { To capture or } \\
\text { resemble real-life } \\
\text { environments } \\
\text { (through space, } \\
\text { equipment or } \\
\text { methodologies). }\end{array}$ & Test-bed-like. & $\begin{array}{l}\text { Natural } \\
\text { setting with } \\
\text { limitations. }\end{array}$ & $\begin{array}{l}\text { Real world with } \\
\text { time and space } \\
\text { limitations. }\end{array}$ & $\begin{array}{l}\text { Real-world } \\
\text { context. No } \\
\text { limitations. }\end{array}$ & $\begin{array}{l}\text { (Schuurman } \\
\text { et al., 2013; } \\
\text { Veeckman et } \\
\text { al., 2013) }\end{array}$ \\
\hline $\begin{array}{l}\text { User-centric } \\
\text { Innovation }\end{array}$ & $\begin{array}{l}\text { To involve users in } \\
\text { the different phases } \\
\text { of the innovation } \\
\text { cycle in which they } \\
\text { can test, evaluate, } \\
\text { contribute and co- } \\
\text { create. }\end{array}$ & $\begin{array}{l}\text { No } \\
\text { interaction } \\
\text { with users. } \\
\text { No } \\
\text { evaluation. } \\
\text { No co- } \\
\text { creation. }\end{array}$ & $\begin{array}{l}\text { Users seen as } \\
\text { passive actors } \\
\text { (testers). } \\
\text { Limited } \\
\text { evaluation. } \\
\text { No decision- } \\
\text { making by } \\
\text { users. }\end{array}$ & $\begin{array}{l}\text { User as } \\
\text { contributor. } \\
\text { Interactive } \\
\text { evaluation. } \\
\text { Feedback may } \\
\text { lead to } \\
\text { modifications. }\end{array}$ & $\begin{array}{l}\text { Users as co- } \\
\text { creators. Multiple } \\
\text { channels and } \\
\text { iterative feedback } \\
\text { from users. }\end{array}$ & $\begin{array}{l}\text { (Schuurman } \\
\text { et al., 2013; } \\
\text { Veeckman et } \\
\text { al., 2013) }\end{array}$ \\
\hline $\begin{array}{l}\text { Culture and } \\
\text { Community }\end{array}$ & $\begin{array}{l}\text { To build an identity } \\
\text { and to grow a } \\
\text { community of } \\
\text { engaged and } \\
\text { motivated users } \\
\text { with access to the } \\
\text { laboratory. }\end{array}$ & $\begin{array}{l}\text { No } \\
\text { community. } \\
\text { No cultural } \\
\text { identity. }\end{array}$ & $\begin{array}{l}\text { Few people } \\
\text { know and } \\
\text { access the } \\
\text { space. } \\
\text { Limited } \\
\text { access to } \\
\text { space. } \\
\text { Contrasting } \\
\text { internal \& } \\
\text { external } \\
\text { images. }\end{array}$ & $\begin{array}{l}\text { Established } \\
\text { community. } \\
\text { Frequent access } \\
\text { and events. } \\
\text { Officially known } \\
\text { cultural identity. }\end{array}$ & $\begin{array}{l}\text { Engaged and } \\
\text { active community. } \\
\text { Cultural identity } \\
\text { and coherent } \\
\text { internal/external. } \\
\text { High frequency of } \\
\text { interaction. }\end{array}$ & $\begin{array}{l}\text { (Moultrie et } \\
\text { al., 2007; } \\
\text { Dupont et al., } \\
\text { 2017) } \\
\text { and author's } \\
\text { experience }\end{array}$ \\
\hline Teamwork & $\begin{array}{l}\text { To enhance } \\
\text { teamwork in } \\
\text { innovation, } \\
\text { encourage better } \\
\text { communication } \\
\text { (physical or } \\
\text { virtual), encourage } \\
\text { formal and informal } \\
\text { social interaction } \\
\text { and motivate staff. }\end{array}$ & $\begin{array}{l}\text { No intent to } \\
\text { enhance } \\
\text { teamwork. }\end{array}$ & $\begin{array}{l}\text { Strictly formal } \\
\text { interaction } \\
\text { between } \\
\text { members. } \\
\text { Hierarchy. }\end{array}$ & $\begin{array}{l}\text { Physical or } \\
\text { virtual } \\
\text { communications } \\
\text { mechanisms. } \\
\text { Staff involved } \\
\text { and motivated } \\
\text { with strategy. }\end{array}$ & $\begin{array}{l}\text { Enhance } \\
\text { teamwork. Boost } \\
\text { communication. } \\
\text { Allow social } \\
\text { interaction (formal } \\
\text { or informal). }\end{array}$ & $\begin{array}{l}\text { (Moultrie et } \\
\text { al., 2007) and } \\
\text { authors' } \\
\text { experience }\end{array}$ \\
\hline Lifespan & $\begin{array}{l}\text { To estimate the } \\
\text { length of the project } \\
\text { as a whole (short-, } \\
\text { medium- or long- } \\
\text { term). }\end{array}$ & $\begin{array}{l}\text { Short-term < } \\
1 \text { year }\end{array}$ & $\begin{array}{l}\text { Medium-term } \\
1-2 \text { years }\end{array}$ & $\begin{array}{l}\text { Long-term 2-3 } \\
\text { years }\end{array}$ & $\begin{array}{l}\text { Very long }+3 \\
\text { years (permanent) }\end{array}$ & $\begin{array}{l}\text { Authors' } \\
\text { experience }\end{array}$ \\
\hline
\end{tabular}

Physical Embodiment: The innovation space itself encompasses all the characteristics of the physical environment. The design of the space varies significantly, with different design values and degrees of flexibility; also, the way the space evolves is contemplated. Different laboratories contain diverse levels of physical resources, from the IT infrastructure and support of prototyping and visualisation to the furniture. Each configuration is realised based on specific constraints such as resources, space, skills and time.

Process of Use: Innovation spaces are forced to adapt to the changing conditions and this may lead 
to new or adapted uses of the space. The way innovation is actually supported, which creative activities are done within the laboratory, or to what degree the space really enables teamwork are some of the elements to take into consideration, but more important is to compare how much this has changed in comparison to the original intent and the process of creation. This could lead to helpful insights to understand the role of the physical space.

Innovation Outcomes: As we talk about innovation laboratories, it is expected that their activity will result in some kind of innovation outcome. However, based on the literature review, there is no clear understanding of which type of results are the ones to determine whether a laboratory is successful or not. Beyond this, it is clear that the activity of innovation laboratories triggers a set of creative and innovative processes with involvement of the community that eventually lead to some positive testimonials and compelling stories (Moultrie, Nilsson et al., 2007). Therefore, it is necessary to examine and define in detail the indicators that would help to assess the innovation performance of this kind of laboratory. For the purpose of this work, innovation outcomes are considered to be those tangible and intangible results which can be duplicable, new and useful in their context (Quintane, Mitch Casselman, Sebastian Reiche \& Nylund, 2011). We will inquire into what those results could be for the innovation laboratory owner, or for its stakeholders and partners.

Moving forward through the path to operationalisation, an international exploratory study is proposed. As was shown before, the international proliferation of claimed laboratories around the world has been significant. Thus, designing an instrument to gather and analyse the experiences of multiple cases fits with the need to complete and ameliorate the grid. This instrument will be a questionnaire intended to reach multiple networks of laboratories, such as Living Labs, Design Factories, ViveLabs, FabLabs and others.

\section{b. Design of instrument and data gathering}

Based on the comprehensive list development in the previous point, an instrument to collect qualitative and quantitative data based on multiple cases was designed. It was co-designed with directors and managers from several innovation laboratories. This questionnaire is based on the 30 criteria defined in the framework and the grid of indicators previously presented. It has 56 questions directly related to the framework plus 14 general questions for classification and feedback purposes for a total of 70 (http://goo.gl/forms/GGPKyxswCK).

The instrument is composed of multiple choice questions as well as checkboxes and open questions. In the first case, we aim to evaluate the maturity level of the laboratory in the correspondent criteria according to the literature. On the other side, the checkboxes and open questions are used to gather data and identify which practices are performed within the laboratories and also to make and inventory actual infrastructure that composes the innovation spaces.

The first version of the instrument was created with the support of the Lorraine Fab Living Lab ${ }^{\circledR}$ in Nancy, France, the Centre for Digital Media in Vancouver, Canada and the ViveLab Bogotá, Colombia.

\section{TESTING THE ASSESSMENT TOOL}

\section{a. General characterisation of laboratories}


Published in Journal of Creativity and Innovation Management - Volume 28:82-100 March 2019

DOI: https://doi.org/10.1111/caim.12301

The instrument was applied in 15 cases on a diverse sample of laboratories from 11 cities and five countries. Among the respondents there are representatives from Living Labs, ViveLabs, Design Factory and Fab Labs, represented mostly by their directors or managers (13 out of 15); this fact guarantees that the information collected is accurate and as close as possible to the reality of the laboratories. A summary of general characteristics is presented in Table 3. The questionnaire captured responses describing functioning details of innovation laboratories, though they also provide valuable insight into the utility and the potential to assess each part of the process. Based on this, it is intended to understand the degree to which the instrument could be used as an assessment tool, taking into account possible errors, misleading questions and points of improvement. Three main cases were handled in earlier applications with a prototype to verify the functioning of the questionnaire, leading to a new version to be used for the following tests with later cases.

Table 3. Full list of laboratories characterised along the dimensions listed in the same table

\begin{tabular}{|c|c|c|c|c|c|}
\hline \multicolumn{6}{|c|}{ Case details } \\
\hline Case & $\begin{array}{c}\text { Date of creation (and } \\
\text { time of operation } \\
\text { when answer, in } \\
\text { month) }\end{array}$ & $\begin{array}{c}\text { Type } \\
\text { (according to the } \\
\text { answers) }\end{array}$ & Employees & $\begin{array}{l}\text { Users per } \\
\text { month }\end{array}$ & $\begin{array}{c}\text { Thematic focus (according to } \\
\text { answers) }\end{array}$ \\
\hline A & $1^{\text {st }}$ December 2010 & Living Lab & 14 & 32 & R\&D in AAL and e-Health \\
\hline B & $\begin{array}{c}13^{\text {th }} \text { November } 2012 \\
(31)\end{array}$ & Design factory & 7 & 40 & $\begin{array}{c}\text { Design Factory Training } \\
\text { Programme }\end{array}$ \\
\hline $\mathrm{C}$ & $\begin{array}{c}2^{\text {nd }} \text { September } 2014 \\
(10)\end{array}$ & Fab Lab & 1 & 80 & $\begin{array}{l}\text { Education, inclusion and } \\
\text { disability }\end{array}$ \\
\hline $\mathrm{D}$ & $25^{\text {th }}$ September 2012 & el & 4 & 70 & $\begin{array}{l}\text { Visual Design Training and } \\
\text { Research }\end{array}$ \\
\hline $\mathrm{E}$ & $29^{\text {th }}$ April 2013 (26) & Vivelab & 12 & 546 & Digital Art Entrepreneurship \\
\hline $\mathrm{F}$ & $1^{\text {st } J a n u a r y ~} 2014$ (18) & $\begin{array}{c}\text { Living Lab }- \text { Fab } \\
\text { Lab }\end{array}$ & 3 & 150 & Fab Living Lab \\
\hline G & $21^{\text {st }}$ July $2015(0)$ & Living Lab & 3 & 10 & Innovation \\
\hline $\mathrm{H}$ & $3^{\text {rd }}$ November 2014 & Coworking & 3 & 20 & Social Innovation \\
\hline I & $28^{\text {th }}$ October $2013(21)$ & Vivelab & 18 & 160 & Digital Content \\
\hline $\mathrm{J}$ & 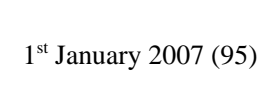 & $\begin{array}{l}\text { Combined applied } \\
\text { research and } \\
\text { design facility }\end{array}$ & 20 & 50 & Digital Media \\
\hline
\end{tabular}


Published in Journal of Creativity and Innovation Management - Volume 28:82-100 March 2019 DOI: https://doi.org/10.1111/caim.12301

\begin{tabular}{|c|c|c|c|c|c|}
\hline K & $\begin{array}{c}1^{\text {st }} \text { November } 2013 \\
\text { (21) }\end{array}$ & Vivelab & 3 & 80 & Animation \& Apps Development \\
\hline $\mathrm{L}$ & $1^{\text {st }}$ August 2005 (120) & Living Lab & 8 & 400 & ICT in Education \\
\hline M & $1^{\text {st }}$ September $2015(0)$ & Living Lab & 1 & 20 & Health - Nervous systems \\
\hline $\mathrm{N}$ & $\begin{array}{c}30^{\text {th }} \text { November } 2014 \\
(30)\end{array}$ & Coworking & 3 & 50 & $\begin{array}{l}\text { Science- \& technology-based } \\
\text { entrepreneurship }\end{array}$ \\
\hline $\mathrm{O}$ & $2^{\text {nd }}$ January 2012 (65) & Makerspace & 4 & 80 & Digital Fabrication \\
\hline
\end{tabular}

Due to space limitations, testing of the questionnaire is mainly described through just four of the case studies, discussing noteworthy observations for each section in which the instrument was divided.

Case B. This laboratory belongs to the Design Factory network. It belongs to a private professional institute and was funded by the national government. It has seven employees, received 40 users per month and is focused on sharing and replicating the Design Factory Training Programme among the students of their institute. The respondent for this case is the manager of the laboratory.

Case F. This corresponds to a living lab that combines the fab lab vision. It is part of a public university, being funded by the regional government. In this case, the manager responded to the questionnaire. The staff is composed of three people and they received more than 150 people per month. Their thematic focus is Fab Living Lab combining ideation, prototyping and evaluation.

Case I. The laboratory was created from a public alliance between the national and regional governments, operated by a public university. They have 18 employees while they welcome about 160 users per month. This laboratory belongs to the ViveLab network and is oriented towards strengthening the digital content industry in their context.

Case J. This is a combined graduate programme and (applied) research and design facility. It belongs to a consortium of universities and their thematic focus is Digital Media. They have a staff of 20 people and have approximately 50 users per month.

\section{b. Application of the instrument - a cross case analysis}

From now on, main insights and learnings from the application of the instrument are discussed. Based on a cross case analysis, usage feedback and learnings are examined as well as instrument shortcomings to be improved.

\section{Strategic intention}

Looking to understand the degree of consciousness in which an innovation laboratory is conceived, several questions were grouped in this section according to our initial maturity grid. Some questions were presented according to the levels of the grid to determine how managers reflect on specific criteria from a strategic perspective. As for the strategic goals, we found that the question seems understandable to respondents reflecting on how they have foreseen the operation of their laboratory.

Contact author: fosoriob@unal.edu.co 
Given that our four cases are strongly related to university environments, it is natural to see that in every case, their objectives aim to provide some kind of service or benefit to their closest communities (students, researchers and professors). However, cases $\mathrm{F}$ and $\mathrm{J}$ are not limited to their university communities and show the intention to link their operation to companies' projects by charging for them to make a sustainable innovation laboratory.

Regarding the possibility that the innovation laboratory could create added value for its partners and the mechanisms to do so, respondents appear to be familiar with it. In this point, Case J shared a clear intention based on intellectual property strategies to make sure that any sponsor company keeps or receives the IP rights and they do not remain exclusively with the university; dedicated staff is in charge of managing relations with the companies; a faculty member is assigned for each project, acting as a facilitator and arranging schedules and deliverables at the beginning of each project. On the other hand, cases B, F and I considered that actions were mostly providing access to the space and equipment, offering free activities and services or organising joint events for dissemination. Based on these examples, it would be possible to feed the maturity grid with enough descriptions for each level.

From the application of the instrument also emerges the necessity to make some adjustments. In this section, for example, the intention for the innovation laboratory to resemble real-life environments was also asked about. These environments are understood as the actions to simulate or recreate specific real-life situations through the space, special equipment or methodologies. According to the obtained answers, in some cases the respondents did not fully understand the question as some of them only focused on whether they considered themselves to have specialised equipment or areas for this purpose. However, this could also be supported by other means, such as particular methodologies, protocols or intended activities. Thus, the levels of maturity should provide a more detailed description to enable better understanding.

From theory (see Section III), building a community of users is a strong element to consider for designing an innovation laboratory strategy linked to its local context. Through this study we wanted to explore how managers of innovation laboratories consider this aspect and gather what the actions were that they intended to implement around this criterion. Cases B, F and I stated they were open to welcoming users not only from their main institutions but from other organisations, whilst for Case $\mathrm{J}$ it was clear that their community will be composed mostly of their registered students and faculty members. Nevertheless, when questions were asked about what types of strategies they expected to utilise, a wide variety of actions were presented, including use of the space during specific hours at no cost, an invitation to be part of ideation or prototyping activities, organising social tech activities (meetups), recognition of their participation through the publication of project results (presentations, reports, online descriptions or blogs). Although Case B asserts that, despite their intention, they have been very limited in implementing those actions due to lack of resources, this is a matter they are willing to improve. This raises the question of how feasible innovation laboratories are and whether they are coherent to their actual capacity and the expected outcomes.

On the perspective of applying the questionnaire to an extensive sample, these kinds of questions would probably contribute to identifying patterns and correlations that would help to better address innovation laboratories' strategies. As we found in this testing sample, even though Cases F and I aimed at long-term objectives, they also noted that, due to resource allocation constraints, the initial estimation time for their laboratories was two or three years initially. Despite the desire to make the laboratory sustainable and permanent, at that moment they were constrained to contractual terms they could not avoid. The ability to identify these sorts of limitations and challenges for innovation laboratories is what we believe to be the value of the instrument, so that practices and experiences can be shared and enriched. 


\section{Process of creation}

Hereafter, the strategic intention begins to be materialised in what ultimately will be the laboratory's embodiment. Still, to reach this phase it is necessary to look over the creation process to assess how the strategy was interpreted towards the implementation of the laboratory. The questionnaire inquires about the intended innovation processes to be carried out, in which respondents were invited to choose from Research, Design, Implementation or Exploitation processes. During the test campaign they also had the opportunity to include any specific process that they considered was not covered by the options, but this was not the case. All of the four cases exhibited a design orientation, while some of them also aimed to include implementation or research processes. In any of the cases, exploitation processes were contemplated, even in those cases in which lifespan and objectives were defined as mid-term or permanent.

For example, Case $\mathrm{J}$ explained that implementation and exploitation processes were intended to be carried out by their clients (mostly companies) and only their laboratory was involved in these processes when students created their own projects and subsequently wished to commercialise the results. In this case, the laboratory provides support for preliminary implementation/exploitation activities. From this, we agree that an innovation laboratory is not meant to commercialise or to mass distribute products; instead, they should favour the promising new solutions to rapidly reach implementation and transfer status. Therefore, it needs to be taken into account that innovation processes are composed of several activities, not all of which need to be performed within the laboratory (e.g. exploitation includes selling, promoting and demonstrating) but if they were somehow considered it would provide valuable support to the transition of the laboratory's outcomes to the real context as they are supposed to. Based on this, we observe that it would be necessary to include additional descriptions in the maturity grid to clarify the possibilities.

Likewise, respondents were also asked about the kind of users they expected to welcome and the frequency. Students, professors, researchers and entrepreneurs appear to be common in the sample. Moreover, depending on the thematic focus of the laboratory, diverse types of users could be linked, such as officials, non-profit organisations, hospitals, mothers, makers etc. From the answers it seems that users' descriptions can be very general, almost superficial, whereas an innovation laboratory is supposed to exceptionally know its users and how to work with them. For this reason, questions in this regard need to be revised to motivate managers to refer to users as individuals describing their behaviours, pains and desires. Subsequently, this also applies to facilitators for which we believe they have a significant role that needs to be carefully chosen and designed to correspond to laboratory users' profiles.

Additionally, the assessment of the creation process was fulfilled, reviewing available resources inquiring about the budget, personnel and intended activities. With this in mind, managers can have a glimpse of how far they are going from the intended strategy even before advancing to implementation. Our reference cases show that investment can vary from less than 500 thousand euros to more than 5 million euros where infrastructure (space and technical resources) represents at least $25 \%$ but can go up to $75 \%$. Therefore, a forecast of the extent to which the laboratory will sporadically receive users or co-located team projects, the required size of the staff to operate the space and what kind of events they must be prepared for seems to be a reasonable task to perform before going through the physical embodiment.

\section{Physical Embodiment}

Contact author: fosoriob@unal.edu.co 
The possibility to gather complementary information about infrastructure, equipment and any special features that could compose an innovation laboratory is also envisioned through this questionnaire. In that sense, the questions for that purpose showed they worked accordingly, as in this test we can observe diverse possibilities for laboratory embodiment from single rooms with a high level of flexibility with almost no IT resources or fabrication technologies (Case B) to multiple fixed areas, moderate levels of flexibility and vast technology options for experimentation (Cases F \& I) to a whole new building specifically designed for the laboratory's purpose with almost every sort of area, resources and technology at their disposal (Case J). It is important to note that these elements based on a bigger sample could be categorised but that does not necessarily mean that a laboratory equipped with much more technological resources could perform better than others with more "elemental" features. Actually, if an intended projection of the laboratory is not strategically designed and consistently realised it will probably lead to its misuse or to outrunning its capacity.

Indeed, advancing from design to implementation is not an easy task. Constraints and limitations are part of every project where adapting and evolving become the alternative to overcome these challenges. Based on our reference cases, we perceive that failing to establish a common vision for the laboratory among stakeholders, operating in heavily bureaucratic environments, and facing a refusal of cultural change seem to be common issues. Therefore, it should be necessary to look back and evaluate if there were elements that could be foreseen and then move forward by proposing the appropriate actions to address the situation. For example, Case B manifested they were facing strong refusals to collaborate and share resources from other units in their institution, being interpreted as lack of will even for inviting their communities to participate in the laboratory. This corresponds to the difficulties they explained during the strategic intention section, where they were unable to foster the sense of community around the laboratory as well as the traditional academic environment in where the laboratory was installed. Although, at this moment it is not possible to provide defining alternatives to address these kinds of situations, the instrument contributes to creating awareness among managers and possible correlations between what was intended and the current implementation.

Subsequently, being prepared to adapt the laboratory in response to emergent needs, technologies or business strategies should be on the radar of innovation laboratories; after all, they are even conceived to lead these changes. The questionnaire also inquires into the degree to which this evolution is planned and in what elements it is mainly thought. Because of this test, ideas, requirements or proposals from new strategies for required technologies were gathered from respondents. Resuming the previous example from Case B, specific actions to improve community engagement and to create a sense of belonging were proposed. Moreover, Case I highlights the necessity to have their own space, not only to satisfy the increasing demand but also to lighten bureaucratic obstacles, while Case $\mathrm{F}$ is focused on the redistribution of the space and Case $\mathrm{J}$ on providing additional technologies. Regarding the questionnaire, we believe this section provides valuable inputs although minor changes are required.

\section{Process of Use}

At this point in the questionnaire, the objective was to inquire into what the actual use of the laboratory is, from a managerial perspective, to determine how far from the intended use it is and what the main changes are which have been adopted. In this regard, Case I has begun to include research processes to strengthen their operation with more systematic and rigorous processes. Furthermore, they continue to perform all the intended creative activities but now evaluation has become a strategic activity due to quality data that has been gathered through carefully designed

Contact author: fosoriob@unal.edu.co 
protocols, which they are even considering offering as a laboratory service to the public. Similarly, Case $\mathrm{J}$ manifested that most of the intended processes are supported and that they are even partially supporting exploitation. For them, there was a perceived need of their users and therefore supporting final commercialisation seemed to be a good fit for them, although the laboratory does not have suitable testing facilities and they must be done on an ad hoc basis. In contrast, Case B explained that they discarded the possibility to include more complex processes, such as research and exploitation, mainly because they are limited by the space and the objectives they defined for the laboratory, whereas Case $\mathrm{F}$ has been primarily focused on improving the coordination among their processes, activities and related technological devices.

Additionally, data related to their capacity, the actual demand and use of the space, as well as the real users they are receiving was also collected. This will help us to identify where the common changes are, as well as the adoption strategies that were used in each case. Nevertheless, as valuable as it is, the managerial perspective of this exploratory test campaign lacks user feedback. This is one of the main challenges for future steps in this research, to actually assess the use of the innovation laboratory from the user's perspective. This would certainly contribute not just to balancing the assessment but would represent a significant source of feedback for managers of innovation laboratories. Regarding the current instrument, there are several questions that need to be revised to capture better insights from managers, but the assessment of the process of use definitely needs to be complemented by other means and scenarios primarily focused on the actual users of each innovation laboratory.

\section{Innovation Outcomes}

Hereafter, the questionnaire was aimed at identifying the set of indicators that could help us determine whether an innovation laboratory is successful or not. The first step was getting to know what sorts of results are in the minds of those who oversee their operation. Then, for the testing purpose we look to examine whether the questions and their respective answers provide enough data to potentially define the corresponding levels of maturity for these criteria. The degree of realised intentions, tangible outcomes, intangible outcomes, level of satisfaction and suggestions for improvement were the aspects that we went through, from which relevant insights were obtained.

As for tangible results, Cases B and I manifested their outcomes as the number of training sessions, workshops and hackathons or design contests performed, as well as the number of communities and the total users that have been received within the laboratory (from visiting to participating). In addition, both laboratories also presented the number of projects supported or incubated in an approximately two-year span. Besides these indicators, Case F also denoted the level of diffusion through the media as well as the scientific recognition due to their research efforts, both forming part of the dissemination strategy of the laboratory. They also referred to the success of one of their partners who benefited from the laboratory's operation as a tangible representation of their impacts. On top of that, Case J seems to have reached a superior level of maturity in this regard, presenting indicators such as the contribution to better prepared companies for product development; sources of new products or product lines ready to commercialise; student-led companies and the enrichment of the local labour pool. These results constitute a worthy example of the use of the instrument and the valuable data that can be gathered to capture not only practices but also possible desired outcomes. This could even be used to distinguish types of laboratories among a bigger sample.

Regarding intangible outcomes, the managers from our reference cases assert innovation laboratories as producing effects over their context and their users that are not necessarily quantifiable. That is to say, change of mindset, attitude and motivation from users towards the activities to be carried out 
under the laboratory seemed to be a positive influence shared by four cases. Likewise, it seems the laboratory itself can trigger people's curiosity, and a sense of belonging and shared learning is created through large-scale events (e.g. hackathons). More than that, the managers believe that the space itself seems to become an iconic place, attracting communities and favouring brand recognition. Thus, evidence indeed shows that intangible results are something that managers of innovation laboratories appear to perceive and something on which they could eventually rely, and therefore they should also be considered in further steps of this research.

\section{c. Implications for the maturity grid and gathering instrument}

As part of the application of the gathering instrument, after a detailed study of the understanding and exchange with respondents, a set of changes were identified. Of the 70 questions which constitute the instrument, nine should be removed or replaced, 12 required major changes, 10 need minor corrections and 39 seem to work properly for the purposes of the research. Those changes also include modifications to the maturity grid where criteria should be updated and detailed descriptions for each level should be added. It was identified that several questions that were built based on short descriptions need to be detailed to facilitate the answer.

Indeed, these detailed descriptions can serve as guidance to better transit from each section and facilitate the assessment that each manager will perform on his or her own laboratory. The fact that this questionnaire has motivated directors and managers of innovation laboratories to express themselves about their objective definition of the reasons for installing the equipment and infrastructure they have seems to create awareness of the influence of the laboratory and the strategic actions to pursue.

Although each laboratory was very different, the instrument seems to be applicable to every one of the three languages in which it was built. In each part, respondents were asked to evaluate their degree of maturity for a certain number of criteria, but they were also asked to explain some of their answers and to share additional thoughts. The thoroughness found in almost every answer, even though there were 70 questions, showed the interest in this issue and the potential value of the tool.

Process of use represents the main challenge and limitation for this tool. Even though we were able to collect data and insights from a managerial point of view, the necessity of actual users' feedback is undeniable. This opens the opportunity to design user-oriented experiments as part of future stages of this research.

The application of this tool also led to numerous ideas and suggestions about what managers of innovation laboratories would like to know in regard to results from this research. These vary from infrastructure-related issues such as space configuration and distribution, software and equipment, and usage rates for each type of area to organisational cultures, methodologies and techniques used for innovation. Likewise, operational and sustainability models were among the requests. Admitting that we may not be able to address each one of these issues, we do find all the ideas encouraging.

\section{DISCUSSION AND LIMITATIONS}

This article studied what the actual capabilities of innovation laboratories are and to which degree of expertise their practices and processes could be determined by proposing a maturity grid-based 
assessment tool. The main contributions of this work are: (1) an updated framework adapted to address innovation laboratories' strategies and capabilities involving stakeholders and communities; (2) a strategy-oriented maturity grid; (3) a multilingual gathering instrument; (4) together, the grid and the instrument envision a prototype of a maturity grid-based design and assessment tool.

The proposed framework makes it possible to study the processes of creation and use of a space intended to support innovation and to measure the outcomes according to the original strategic intention. Based on an existing and mostly theoretical framework, an updated version was proposed and operationalised. According to the literature review, it is an original contribution to the recent research efforts to understand the behaviour and performance of innovation laboratories. This conceptual basis enabled us to build an instrument (questionnaire) that allows a particular innovation laboratory to self-evaluate its degree of maturity, as well as to carry out comparative studies between laboratories. This work evidences the concern to understand the influence of the physical environment in the innovation processes and through the application cases it glimpses a guidance tool for those who want to start a new project aimed at creation of an innovation space.

The main contribution of this work is the basic construction for a maturity grid-based assessment tool for those who want to address and understand the capabilities of an innovation laboratory. Through this, we aim to build a tool whereby researchers and practitioners can find a comprehensive set of practices and experiences in the way that innovation laboratories have been implemented to build their own strategy. Furthermore, we hope this research strengthens the collaborative innovation process. Innovation laboratories are indeed places of knowledge exchange and interaction between communities.

In general, it has been seen that the questionnaire (instrument) itself works as a guidance tool to help managers evaluate the outcomes of an innovation laboratory and potentially carry out the planning of a new innovation space project in a more comprehensive way. As part of the feedback, some respondents underlined that in the early stages of their projects they had not taken into consideration several criteria or elements that are strategic for the success of innovation laboratories. The same instrument also serves for self-testing of the laboratories on the degree of maturity reached, which supports decision-making in regard to the direction to follow in a strategic context.

However, because this is an exploratory study, in future research the efforts will focus on increasing the number of laboratories surveyed, with the aim of improving the results presented in this work. Equally, the methodology needs to improve the process of considering additional elements from users' perceptions and the context in which the innovation laboratory operates. Feedback from respondents suggests the methodology should include some interviews that are held directly in the laboratory to acquire more data. Some other comments suggest that the questionnaire must also consider, for example: social software, percentage of use of each room or area (and why), other spaces that are not work-related, co-creation methodologies, the community's point of view, and innovation techniques. To improve this qualitative approach, we suggest turning this exploratory survey into a mixed approach, using qualitative and quantitative methods (Krawczyk, Topolewski \& Pallot, 2017).

\section{CONCLUSION}

This article introduces an updated vision of innovation laboratories adapted to the context of our society - more open, more virtually distributed, accelerated by digitalisation etc. To support this vision, this research developed and proposed a maturity-based assessment tool as an alternative to determine innovation laboratories capabilities. The methodology, based on an international survey 
with a self-administered questionnaire translated into three languages, emphasises the evaluation of the intended strategy and process of creation versus the physical embodiment and the actual usage of the laboratory. In application, it makes possible the capture of practices and experiences that ultimately will contribute to consolidating the assessment tool. Finally, research efforts remain in exploring this issue in greater depth by studying the users' perspectives in the performance of the physical space. Likewise, it is necessary to move forward in the characterisation of outcomes from an innovation laboratory.

\section{ACKNOWLEDGMENTS}

The authors would like to thank all the partners of the LILA project (Living Labs Application for start-up companies) for their participation in this research work. The LILA project is co-funded by Interreg IV-B North West Europe. Also, thanks for the support of Proyectos Basal USA 1555. Vridei 061717PB_MOV Universidad de Santiago de Chile. Likewise, the authors are truly thankful for Professor Richard Smith and the Centre of Digital Media of Vancouver, Canada for their valuable contributions to this work.

\section{REFERENCES}

Amabile, T. M. (1988). A model of creativity and innovation in organizations. Research in Organizational Behavior, 10(1), 123-167.

Andersen, E. S., \& Jessen, S. A. (2003). Project maturity in organisations. International Journal of Project Management, 21(6), 457-461. https://doi.org/10.1016/S0263-7863(02)00088-1

Andersson Schaeffer, J., \& Eriksson, Y. (2014). Tool-complexes of innovation. : Spaces for explorative innovation in four manufacturing companies. In Design Research Society Biennial International Conference 16-19 June 2014, Umeå, Sweden (Vol. 1, pp. 663-676). Umeå: Mälardalen University, Innovation and Product Realisation.

Claire, J., Galvez, D., Boly, V., Camargo, M., \& Moselle, J. C. (2014). A new innovation project maturity assessment methodology based on innovation degree. In 2014 International Conference on Engineering, Technology and Innovation (ICE) (pp. 1-8). Bergamo: IEEE. https://doi.org/10.1109/ICE.2014.6871614

Del Vecchio, P., Elia, G., Ndou, V., Secundo, G., \& Specchia, F. (2017). Living Lab as an Approach to Activate Dynamic Innovation Ecosystems and Networks: An Empirical Study. International Journal of Innovation and Technology Management, 14(05), 1750024. https://doi.org/10.1142/S0219877017500249

Dupont, L. (2009, November 5). Transfert du génie industriel vers l'ingénierie urbaine : vers une approche collaborative des projets urbains. Institut National Polytechnique de Lorraine INPL.

Dupont, L., Gabriel, A., Camargo, M., \& Guidat, C. (2017). Collaborative innovation projects engaging open communities: A case study on emerging challenges. In 2017 International Conference on Engineering, Technology and Innovation (ICE/ITMC) (pp. 1082-1091). IEEE. https://doi.org/10.1109/ICE.2017.8280002

Dupont, L., Guidat, C., Morel, L., \& Skiba, N. (2016). The role of mock-ups in the anticipation of the user experience within a living lab: An empirical study. In 2015 IEEE International Conference on Engineering, Technology and Innovation/International Technology Management Conference, ICE/ITMC 2015 (pp. 1-8). IEEE. https://doi.org/10.1109/ICE.2015.7438669

Dupont, L., Morel, L., \& Guidat, C. (2015). Innovative public-private partnership to support Smart City: the case of "Chaire REVES". Journal of Strategy and Management, 8(3), 245-265. https://doi.org/10.1108/JSMA-03-2015-0027

Dupont, L., Morel, L., Hubert, J., \& Guidat, C. (2014). Study case: Living Lab Mode for urban 
Published in Journal of Creativity and Innovation Management - Volume 28:82-100 March 2019

DOI: https://doi.org/10.1111/caim.12301

project design: Emergence of an ad hoc methodology through collaborative innovation. In 2014 International Conference on Engineering, Technology and Innovation (ICE) (pp. 1-9). IEEE. https://doi.org/10.1109/ICE.2014.6871550

Dupont, L., Morel, L., \& Lhoste, P. (2015). Le Lorraine Fab Living Lab : la 4 `eme dimension de l'innovation. In Actes des Journées Hubert Curien, session Médiation Scientifique, territorialité et développement local, Colloque Science \& You (pp. 230-235). Nancy: Université de Lorraine.

Ekvall, G. (1997). Organizational Conditions and Levels of Creativity. Creativity and Innovation Management, 6(4), 195-205. https://doi.org/10.1111/1467-8691.00070

Gey, R., Meyer, L. P., \& Thieme, M. (2013). A Conceptual Framework for Describing the Phenomenon Innovation Laboratory: A Structurational Viewpoint. In XXIII International RESER Conference (pp. 1-17). Aix-En-Provence.

Griffin, R., \& Michele Kacmar, K. (1991). Laboratory research in management: Misconceptions and missed opportunities. Journal of Organizational Behavior, 12(4), 301-311. https://doi.org/10.1002/job.4030120405

Gryszkiewicz, L., Lykourentzou, I., \& Toivonen, T. (2016). Innovation Labs: Leveraging Openness for Radical Innovation? Journal of Innovation Management, 4, 68-97.

Kallio, T. J., Kallio, K.-M., \& Blomberg, A. J. (2015). Physical space, culture and organisational creativity - a longitudinal study. Facilities, 33(5/6), 389-411. https://doi.org/10.1108/F-092013-0074

Klooker, M., Matzdorf, S., Nicolai, C., Boettcher, L., \& Trost, A. (2015). The Importance of Strategic Intent in Developing Innovation Space. In ISPIM Innovation Symposium. The International Society for Professional Innovation Management (ISPIM). Brisbane.

Krawczyk, P., Topolewski, M., \& Pallot, M. (2018). Towards a reliable and valid mixed methods instrument in user eXperience studies. In 2017 International Conference on Engineering, Technology and Innovation: Engineering, Technology and Innovation Management Beyond 2020: New Challenges, New Approaches, ICE/ITMC 2017 - Proceedings (Vol. 2018-Janua, pp. 1455-1464). IEEE. https://doi.org/10.1109/ICE.2017.8280054

Kristensen, T. (2004). The Physical Context of Creativity. Creativity and Innovation Management, 13(2), 89-96. https://doi.org/10.1111/j.0963-1690.2004.00297.x

Lewis, M., \& Moultrie, J. (2005). The Organizational Innovation Laboratory. Creativity and Innovation Management, 14(1), 73-83. https://doi.org/10.1111/j.1467-8691.2005.00327.x

Maier, A. M., Moultrie, J., \& Clarkson, P. J. (2012). Assessing Organizational Capabilities: Reviewing and Guiding the Development of Maturity Grids. IEEE Transactions on Engineering Management, 59(1), 138-159. https://doi.org/10.1109/TEM.2010.2077289

Morel, L., Dupont, L., \& Boudarel, M.-R. (2018). Innovation spaces: new places for collective intelligence? In D. Uzunidis (Ed.), Collective Innovation Processes (Volume 4). New York: Wiley-ISTE.

Mortara, L., \& Parisot, N. (2018). How do fab-spaces enable entrepreneurship? Case studies of 'makers' - entrepreneurs. International Journal of Manufacturing Technology and Management, 32(1), 16. https://doi.org/10.1504/IJMTM.2018.089465

Moultrie, J., Clarkson, P. J., \& Probert, D. (2007). Development of a design audit tool for SMEs. Journal of Product Innovation Management, 24(4), 335-368. https://doi.org/10.1111/j.15405885.2007.00255.x

Moultrie, J., Nilsson, M., Dissel, M., Haner, U.-E., Janssen, S., \& Van der Lugt, R. (2007). Innovation Spaces: Towards a Framework for Understanding the Role of the Physical Environment in Innovation. Creativity and Innovation Management, 16(1), 53-65. https://doi.org/10.1111/j.1467-8691.2007.00419.x

Nunamaker, J. F., Applegate, L. M., \& Konsynski, B. R. (1988). Computer-Aided Deliberation: Model Management and Group Decision Support. Operations Research, 36(6), 826-848. https://doi.org/10.1287/opre.36.6.826

Contact author: fosoriob@unal.edu.co 
Published in Journal of Creativity and Innovation Management - Volume 28:82-100 March 2019

DOI: https://doi.org/10.1111/caim.12301

Orlikowski, W. J., Yates, J., Okamura, K., \& Fujimoto, M. (1995). Shaping Electronic Communication: The Metastructuring of Technology in the Context of Use. Organization Science, 6(4), 423-444. https://doi.org/10.1287/orsc.6.4.423

Osorio Bustamante, F., Pena Reyes, J. I., Camargo, M., \& Dupont, L. (2015). Spaces to foster and sustain innovation: Towards a conceptual framework. In 2015 IEEE International Conference on Engineering, Technology and Innovation/International Technology Management Conference (ICE/ITMC) (pp. 1-7). Belfast: IEEE. https://doi.org/10.1109/ICE.2015.7438661

Pallot, M., Trousse, B., Senach, B., \& Scapin, D. (2010). Living Lab Research Landscape: From User Centred Design and User Experience towards User Cocreation. In First European Summer School 'Living Labs'.

Peschl, M. F., \& Fundneider, T. (2012). Spaces enabling game-changing and sustaining innovations: why space matters for knowledge creation and innovation. Journal of Organisational Transformation \& Social Change, 9(1), 41-61. https://doi.org/10.1386/jots.9.1.41_1

Peschl, M. F., \& Fundneider, T. (2014). Designing and Enabling Spaces for collaborative knowledge creation and innovation: From managing to enabling innovation as socioepistemological technology. Computers in Human Behavior, 37, 346-359. https://doi.org/10.1016/j.chb.2012.05.027

Prefontaine, C. (2012). Innovation Spaces, Take Two. Retrieved 17 June 2018, from https:/tascha.uw.edu/2012/08/innovation-spaces-take-two/

Quintane, E., Mitch Casselman, R., Sebastian Reiche, B., \& Nylund, P. A. (2011). Innovation as a knowledge-based outcome. Journal of Knowledge Management, 15(6), 928-947. https://doi.org/10.1108/13673271111179299

Schuurman, D., Baccarne, B., Kawsar, F., Seys, C., Veeckman, C., De Marez, L., \& Ballon, P. (2013). Living labs as quasi-experiments: results from the Flemish LeYLab. In XXIV ISPIM Conference : Innovating in Global Markets: Challenges for Sustainable Growth (pp. 1-15). The International Society for Professional Innovation Management (ISPIM).

Shirahada, K., \& Hamazaki, K. (2013). Trial and error mindset of R\&D personnel and its relationship to organizational creative climate. Technological Forecasting and Social Change, 80(6), 1108-1118. https://doi.org/10.1016/j.techfore.2012.09.005

Skiba, N. (2014). Processus d'innovation centré sur l'utilisateur : identification des besoins et interprétation de données issues de l'intégration de l'utilisateur dans le processus de coconception. Université de Lorraine.

Skiba, N., Dupont, L., Morel, L., \& Guidat, C. (2012). A space for innovation process acceleration, supporting collaborative citizens workshops. In 2012 18th International ICE Conference on Engineering, Technology and Innovation (pp. 1-9). IEEE. https://doi.org/10.1109/ICE.2012.6297646

Snead, L., \& Wycoff, J. (1999). TOOLS@ WORK: Stimulating innovation with collaboration rooms. Journal for Quality and Participation, 55-57.

Stercken, A. A. M. (2015, January 27). Cultivating Serendipity and Efficacy Beliefs: The Impact of (Caireen) Innovation Spaces on Human Development. Utrecht University.

Veeckman, C., Schuurman, D., Leminen, S., Lievens, B., \& Westerlund, M. (2013). Characteristics and their outcomes in living labs: a Flemish-finnish case study. In XXIV ISPIM Conference: Innovating in Global Markets: Challenges for Sustainable Growth (pp. 1-24).

Veeckman, C., Schuurman, D., Leminen, S., \& Westerlund, M. (2013). Linking Living Lab Characteristics and Their Outcomes: Towards a Conceptual Framework. Technology Innovation Management Review, 3(2), 6-15.

Villani, E., Rasmussen, E., \& Grimaldi, R. (2017). How intermediary organizations facilitate university-industry technology transfer: A proximity approach. Technological Forecasting and Social Change, 114, 86-102. https://doi.org/10.1016/J.TECHFORE.2016.06.004

Wagner, J., \& Watch, D. (2017). Innovation spaces: The new design of work. Washington, D.C.

Contact author: fosoriob@unal.edu.co 
Published in Journal of Creativity and Innovation Management - Volume 28:82-100 March 2019

DOI: https://doi.org/10.1111/caim.12301

Woodman, R. W., Sawyer, J. E., \& Griffin, R. W. (1993). Toward a theory of organizational creativity. Academy of Management Review, 18(2), 293-321.

https://doi.org/10.5465/AMR.1993.3997517

\section{Appendix 1. Maturity Grids for the strategic intentions framework}

\section{Strategic Intention}

\begin{tabular}{|c|c|c|c|c|c|c|}
\hline Criteria & Description & Level 1 & Level 2 & Level 3 & Level 4 & Reference \\
\hline $\begin{array}{l}\text { Strategic } \\
\text { Goals }\end{array}$ & $\begin{array}{l}\text { To support } \\
\text { organisation / } \\
\text { partnership mission }\end{array}$ & $\begin{array}{l}\text { No goals } \\
\text { defined }\end{array}$ & $\begin{array}{l}\text { Short-term } \\
\text { goals. Not } \\
\text { measurable. }\end{array}$ & $\begin{array}{l}\text { Medium-term } \\
\text { goals. Clear } \\
\text { thematic goals. } \\
\text { Measurable. }\end{array}$ & $\begin{array}{l}\text { Long-term and } \\
\text { sustainability goals. } \\
\text { Measurable. }\end{array}$ & $\begin{array}{l}\text { (Moultrie et } \\
\text { al., 2007) }\end{array}$ \\
\hline $\begin{array}{l}\text { Ecosystem } \\
\text { Approach }\end{array}$ & $\begin{array}{l}\text { To generate added } \\
\text { value for all the } \\
\text { stakeholders } \\
\text { involved, creating } \\
\text { long-term } \\
\text { engagement and } \\
\text { identification with } \\
\text { the laboratory. }\end{array}$ & $\begin{array}{l}\text { No value } \\
\text { creation. No } \\
\text { sharing for } \\
\text { stakeholders. }\end{array}$ & $\begin{array}{l}\text { Partially } \\
\text { Sharing. } \\
\text { Missing links } \\
\text { between } \\
\text { stakeholders. } \\
\text { No equal } \\
\text { contribution. }\end{array}$ & $\begin{array}{l}\text { Value and sharing } \\
\text { for most of the } \\
\text { stakeholders. }\end{array}$ & $\begin{array}{l}\text { Value creation and } \\
\text { sharing for all } \\
\text { stakeholders. Long } \\
\text { engagement. }\end{array}$ & $\begin{array}{l}\text { (Dupont et al., } \\
2014 ; \\
\text { Veeckman et } \\
\text { al., 2013) }\end{array}$ \\
\hline $\begin{array}{l}\text { Real-world } \\
\text { Context }\end{array}$ & $\begin{array}{l}\text { To capture or } \\
\text { resemble real-life } \\
\text { environments } \\
\text { (through space, } \\
\text { equipment or } \\
\text { methodologies). }\end{array}$ & Test-bed-like. & $\begin{array}{l}\text { Natural setting } \\
\text { with } \\
\text { limitations. }\end{array}$ & $\begin{array}{l}\text { Real world with } \\
\text { time and space } \\
\text { limitations. }\end{array}$ & $\begin{array}{l}\text { Real-world context. } \\
\text { No limitations. }\end{array}$ & $\begin{array}{l}\text { (Schuurman } \\
\text { et al., 2013; } \\
\text { Veeckman et } \\
\text { al., 2013) }\end{array}$ \\
\hline $\begin{array}{l}\text { User- } \\
\text { centric } \\
\text { Innovation }\end{array}$ & $\begin{array}{l}\text { To involve users in } \\
\text { the different phases } \\
\text { of the innovation } \\
\text { cycle in which they } \\
\text { can test, evaluate, } \\
\text { contribute and co- } \\
\text { create. }\end{array}$ & $\begin{array}{l}\text { No interaction } \\
\text { with users. } \\
\text { No } \\
\text { evaluation. } \\
\text { No co- } \\
\text { creation. }\end{array}$ & $\begin{array}{l}\text { Users seen as } \\
\text { passive actors } \\
\text { (testers). } \\
\text { Limited } \\
\text { evaluation. No } \\
\text { decision } \\
\text { making by } \\
\text { users. }\end{array}$ & $\begin{array}{l}\text { User as } \\
\text { contributor. } \\
\text { Interactive } \\
\text { evaluation. } \\
\text { Feedback may } \\
\text { lead to } \\
\text { modifications. }\end{array}$ & $\begin{array}{l}\text { Users as co- } \\
\text { creators. Multiple } \\
\text { channels and } \\
\text { iterative feedback } \\
\text { from users. }\end{array}$ & $\begin{array}{l}\text { (Schuurman } \\
\text { et al., 2013; } \\
\text { Veeckman et } \\
\text { al., 2013) }\end{array}$ \\
\hline $\begin{array}{l}\text { Culture } \\
\text { and } \\
\text { Community }\end{array}$ & $\begin{array}{l}\text { To build an identity } \\
\text { and to grow a } \\
\text { community of } \\
\text { engaged and } \\
\text { motivated users } \\
\text { with access to the } \\
\text { laboratory. }\end{array}$ & $\begin{array}{l}\text { No } \\
\text { community. } \\
\text { No cultural } \\
\text { identity. }\end{array}$ & $\begin{array}{l}\text { Few people } \\
\text { know and } \\
\text { access the } \\
\text { space. Limited } \\
\text { access to } \\
\text { space. } \\
\text { Contrasting } \\
\text { internal \& } \\
\text { external } \\
\text { images. }\end{array}$ & $\begin{array}{l}\text { Established } \\
\text { community. } \\
\text { Frequent access } \\
\text { and events. } \\
\text { Officially known } \\
\text { cultural identity. }\end{array}$ & $\begin{array}{l}\text { Engaged and active } \\
\text { community. } \\
\text { Cultural identity } \\
\text { and coherent } \\
\text { internal/external. } \\
\text { High frequency of } \\
\text { interaction. }\end{array}$ & $\begin{array}{l}\text { (Moultrie et } \\
\text { al., 2007; } \\
\text { Dupont et al., } \\
\text { 2017) } \\
\text { and author's } \\
\text { experience }\end{array}$ \\
\hline
\end{tabular}


Published in Journal of Creativity and Innovation Management - Volume 28:82-100 March 2019

DOI: https://doi.org/10.1111/caim.12301

\begin{tabular}{|c|c|c|c|c|c|c|}
\hline Teamwork & $\begin{array}{l}\text { To enhance } \\
\text { teamwork in } \\
\text { innovation, } \\
\text { encourage better } \\
\text { communication } \\
\text { (physical or } \\
\text { virtual), encourage } \\
\text { formal and } \\
\text { informal social } \\
\text { interaction and } \\
\text { motivate staff. }\end{array}$ & $\begin{array}{l}\text { No intent to } \\
\text { enhance } \\
\text { teamwork. }\end{array}$ & $\begin{array}{l}\text { Strictly formal } \\
\text { interaction } \\
\text { between } \\
\text { members. } \\
\text { Hierarchy. }\end{array}$ & $\begin{array}{l}\text { Physical or virtual } \\
\text { communications } \\
\text { mechanisms. Staff } \\
\text { involved and } \\
\text { motivated with } \\
\text { strategy. }\end{array}$ & $\begin{array}{l}\text { Enhance teamwork. } \\
\text { Boost } \\
\text { communication. } \\
\text { Allow social } \\
\text { interaction (formal } \\
\text { or informal). }\end{array}$ & $\begin{array}{l}\text { (Moultrie et } \\
\text { al., 2007) and } \\
\text { author's } \\
\text { experience }\end{array}$ \\
\hline Lifespan & $\begin{array}{l}\text { To estimate the } \\
\text { length of the } \\
\text { project as a whole } \\
\text { (short-, medium- or } \\
\text { long-term). }\end{array}$ & $\begin{array}{l}\text { Short-term < } \\
1 \text { year }\end{array}$ & $\begin{array}{l}\text { Medium-term } \\
1-2 \text { years }\end{array}$ & $\begin{array}{l}\text { Long-term 2-3 } \\
\text { years }\end{array}$ & $\begin{array}{l}\text { Very long }+3 \text { years } \\
\text { (permanent) }\end{array}$ & $\begin{array}{l}\text { Authors' } \\
\text { experience }\end{array}$ \\
\hline
\end{tabular}

\section{Process of Creation}

\begin{tabular}{|c|c|c|c|c|c|c|}
\hline Criteria & Description & Level 1 & Level 2 & Level 3 & Level 4 & Ref. \\
\hline $\begin{array}{l}\text { Intended } \\
\text { Innovation } \\
\text { Processes }\end{array}$ & $\begin{array}{l}\text { Research, Design, } \\
\text { Implementation or } \\
\text { Operation. }\end{array}$ & $\begin{array}{l}\text { At least } 1 \\
\text { process }\end{array}$ & 2 processes & 3 processes & $\begin{array}{l}\text { All innovation } \\
\text { processes }\end{array}$ & \multirow{5}{*}{$\begin{array}{l}\text { (Moultrie et } \\
\text { al., 2007) } \\
\text { and author's } \\
\text { experience }\end{array}$} \\
\hline $\begin{array}{l}\text { Intended } \\
\text { Creative } \\
\text { Activities }\end{array}$ & $\begin{array}{l}\text { Search, synthesis, } \\
\text { creation, prototyping } \\
\text { or evaluation. }\end{array}$ & $\begin{array}{l}\text { At least } 2 \\
\text { activities }\end{array}$ & 3 activities & 4 activities & $\begin{array}{l}\text { Full creative } \\
\text { activities are } \\
\text { held in the } \\
\text { space. }\end{array}$ & \\
\hline $\begin{array}{l}\text { Potential } \\
\text { users and } \\
\text { facilitators }\end{array}$ & $\begin{array}{l}\text { The intended users of } \\
\text { the space: from } \\
\text { occasional test users } \\
\text { or students to } \\
\text { dedicated } \\
\text { environments for co- } \\
\text { located project teams. }\end{array}$ & $\begin{array}{l}\text { Occasional } \\
\text { teams (test } \\
\text { or creative). } \\
\text { Technical } \\
\text { assistant. }\end{array}$ & $\begin{array}{l}\text { Crowd of users } \\
\text { and active } \\
\text { people in events. } \\
\text { Facilitators and } \\
\text { assistant. }\end{array}$ & $\begin{array}{l}\text { Iterative project } \\
\text { team active in the } \\
\text { space. Professors, } \\
\text { researchers, } \\
\text { facilitators. }\end{array}$ & $\begin{array}{l}\text { Co-located } \\
\text { team projects. } \\
\text { People from } \\
\text { community } \\
\text { acting as } \\
\text { facilitators. }\end{array}$ & \\
\hline $\begin{array}{l}\text { Available } \\
\text { resources \& } \\
\text { constraints }\end{array}$ & $\begin{array}{l}\text { The intended } \\
\text { availability of } \\
\text { physical, financial, } \\
\text { human and technical } \\
\text { resources. }\end{array}$ & $\begin{array}{l}\text { No dedicated } \\
\text { space. } \\
\text { Budget } \\
<500 k \text { EUR. } \\
\text { Staff }<2\end{array}$ & $\begin{array}{l}\text { Rented space. } \\
\text { Budget: <2M } \\
\text { EUR. Staff: }<10\end{array}$ & $\begin{array}{l}\text { Own adapted space. } \\
\text { Budget: <5M EUR. } \\
\text { Staff: }<20\end{array}$ & $\begin{array}{l}\text { New physical } \\
\text { space from } \\
\text { scratch. } \\
\text { Budget: >5M } \\
\text { EUR. Staff: at } \\
\text { disposal. }\end{array}$ & \\
\hline $\begin{array}{l}\text { Intended } \\
\text { events }\end{array}$ & $\begin{array}{l}\text { The type of "events" } \\
\text { intended in the space, } \\
\text { from one-off } \\
\text { meetings to ongoing } \\
\text { project work. }\end{array}$ & $\begin{array}{l}\text { One-off } \\
\text { meetings }\end{array}$ & $\begin{array}{l}\text { Classic } \\
\text { class/group } \\
\text { activities (fixed). } \\
\text { Creativity } \\
\text { sessions. } \\
\text { Showrooms. } \\
\text { Access to } \\
\text { technical } \\
\text { resources. }\end{array}$ & $\begin{array}{l}\text { Dynamic project } \\
\text { sessions. Open } \\
\text { networking } \\
\text { meetings. } \\
\text { Jams/marathons. }\end{array}$ & $\begin{array}{l}\text { Co-located } \\
\text { external } \\
\text { projects. }\end{array}$ & \\
\hline
\end{tabular}

\section{Physical Embodiment}

\begin{tabular}{|c|c|c|c|c|c|c|}
\hline Criteria & Description & Level 1 & Level 2 & Level 3 & Level 4 & Ref. \\
\hline $\begin{array}{l}\text { Geographic } \\
\text { Location }\end{array}$ & $\begin{array}{l}\text { The physical location of } \\
\text { the environment and its } \\
\text { relationship with the firm. }\end{array}$ & $\begin{array}{l}\text { Standard } \\
\text { office }\end{array}$ & $\begin{array}{l}\text { Third-party } \\
\text { external facilities }\end{array}$ & $\begin{array}{l}\text { Already existing } \\
\text { lab }\end{array}$ & $\begin{array}{l}\text { New own } \\
\text { dedicated } \\
\text { space }\end{array}$ & $\begin{array}{l}\text { (Moultrie } \\
\text { et al., } \\
2007 \text { and }\end{array}$ \\
\hline
\end{tabular}


Published in Journal of Creativity and Innovation Management - Volume 28:82-100 March 2019 DOI: https://doi.org/10.1111/caim.12301

\begin{tabular}{|c|c|c|c|c|c|c|}
\hline & $\begin{array}{l}\text { This might range from } \\
\text { standard office space to } \\
\text { third-party external } \\
\text { facilities. }\end{array}$ & & & & & \multirow[t]{2}{*}{$\begin{array}{l}\text { author's } \\
\text { experience }\end{array}$} \\
\hline Scale & $\begin{array}{l}\text { The physical scale of the } \\
\text { environment. }\end{array}$ & $\begin{array}{l}\text { Single room } \\
(<100 \mathrm{~m} 2)\end{array}$ & $\begin{array}{l}\text { Multiple fixed } \\
\text { spaces }(<200 \mathrm{~m} 2)\end{array}$ & $\begin{array}{l}\text { Dynamic multiple } \\
\text { rooms }(<400 \mathrm{~m} 2)\end{array}$ & $\begin{array}{l}\text { Dedicated } \\
\text { building } \\
(>400 \mathrm{~m} 2)\end{array}$ & \\
\hline $\begin{array}{l}\text { Real vs. } \\
\text { Virtual }\end{array}$ & $\begin{array}{l}\text { The degree to which the } \\
\text { space is designed around } \\
\text { virtual teamwork and } \\
\text { communication. }\end{array}$ & $\begin{array}{l}\text { Only real } \\
\text { (physical) } \\
\text { communicat } \\
\text { ions }\end{array}$ & $\begin{array}{l}\text { Partially virtual } \\
\text { communications }\end{array}$ & $\begin{array}{l}\text { Advanced virtual } \\
\text { communications }\end{array}$ & $\begin{array}{l}\text { Decentralised } \\
\text { lab interaction }\end{array}$ & \\
\hline Flexibility & $\begin{array}{l}\text { The degree of flexibility } \\
\text { embodied in the } \\
\text { environment to enable } \\
\text { alternative configurations } \\
\text { and uses. The degree of } \\
\text { flexibility/reconfigurability } \\
\text { of resources in the } \\
\text { workspace. }\end{array}$ & Fixed space & $\begin{array}{l}\text { Poor flexibility. } \\
\text { Hard effort to } \\
\text { adapt }\end{array}$ & $\begin{array}{l}\text { Acceptable } \\
\text { reconfigurability } \\
\text { of spaces }\end{array}$ & $\begin{array}{l}\text { Smooth } \\
\text { adaptation to } \\
\text { reconfigure } \\
\text { new } \\
\text { experiences }\end{array}$ & \\
\hline $\begin{array}{l}\text { Design } \\
\text { Values }\end{array}$ & $\begin{array}{l}\text { Specific design values } \\
\text { targeted at encouraging } \\
\text { specific behaviours. The } \\
\text { use of imagery to reinforce } \\
\text { actions. }\end{array}$ & $\begin{array}{l}\text { No presence } \\
\text { of intended } \\
\text { design } \\
\text { values }\end{array}$ & $\begin{array}{l}\text { Some design is } \\
\text { used. "Good } \\
\text { looking lab" }\end{array}$ & $\begin{array}{l}\text { Partially adopted } \\
\text { design values to } \\
\text { encourage } \\
\text { behaviours }\end{array}$ & $\begin{array}{l}\text { Use of design } \\
\text { values \& } \\
\text { imagery to } \\
\text { encourage } \\
\text { specific } \\
\text { behaviours or } \\
\text { actions }\end{array}$ & \\
\hline IT Resources & $\begin{array}{l}\text { The role of IT to enable } \\
\text { group work, activities and } \\
\text { processes. }\end{array}$ & $\begin{array}{l}\text { Basic tools } \\
\text { (for } \\
\text { presentation } \\
\text { ) }\end{array}$ & $\begin{array}{l}\text { L1+ } \\
\text { Common IT tools } \\
\text { (Virtual } \\
\text { communications } \\
\text { are supported) }\end{array}$ & $\begin{array}{l}\text { L2 + Advanced } \\
\text { level } \\
\text { (Interactivity, } \\
\text { Project } \\
\text { Management } \\
\text { Software, Social } \\
\text { Networks) }\end{array}$ & $\begin{array}{l}\text { L3 + } \\
\text { Availability of } \\
\text { high-end } \\
\text { technologies to } \\
\text { fully support } \\
\text { innovation } \\
\text { processes and } \\
\text { creative } \\
\text { activities }\end{array}$ & \\
\hline $\begin{array}{l}\text { Data and } \\
\text { information }\end{array}$ & $\begin{array}{l}\text { The availability of local } \\
\text { data/information to support } \\
\text { innovation, creativity or } \\
\text { design processes/activities. }\end{array}$ & $\begin{array}{l}\text { No access to } \\
\text { info and } \\
\text { data }\end{array}$ & $\begin{array}{l}\text { In-house library. } \\
\text { Internet access }\end{array}$ & $\begin{array}{l}\text { Limited access to } \\
\text { academic } \\
\text { databases }\end{array}$ & $\begin{array}{l}\text { Full access to } \\
\text { libraries and } \\
\text { databases } \\
\text { (Gov., } \\
\text { Academic, } \\
\text { Patents) }\end{array}$ & \\
\hline $\begin{array}{l}\text { Prototyping } \\
\& \\
\text { Visualisation }\end{array}$ & $\begin{array}{l}\text { Availability of equipment, } \\
\text { facilities and tools to } \\
\text { support/enable modelling } \\
\text { and visualisation activities } \\
\text { as a core component of } \\
\text { creative and design } \\
\text { processes. }\end{array}$ & $\begin{array}{l}\text { Simple } \\
\text { paper tools } \\
\text { (cardboard) }\end{array}$ & $\begin{array}{l}\mathrm{L} 1+ \\
\text { Basic printing } \\
\text { and soft } \\
\text { modelling }\end{array}$ & $\begin{array}{l}\mathrm{L} 2+ \\
\text { Set of 3D } \\
\text { printing, laser } \\
\text { cuts, CAD } \\
\text { software }\end{array}$ & $\begin{array}{l}\mathrm{L} 3+ \\
3 \mathrm{D} \text { immersion, } \\
\text { drones, } \\
\text { holographic } \\
\text { VR }\end{array}$ & \\
\hline Constraints & $\begin{array}{l}\text { Practical constraints on the } \\
\text { design of the environment. }\end{array}$ & $\begin{array}{l}\text { Administrati } \\
\text { ve, legal \& } \\
\text { finance } \\
\text { issues }\end{array}$ & $\begin{array}{l}\text { Lack of tech } \\
\text { skills (personnel) }\end{array}$ & $\begin{array}{l}\text { Lack of design } \\
\text { and architectural } \\
\text { "feeling" }\end{array}$ & $\begin{array}{l}\text { Physical space } \\
\text { limitations }\end{array}$ & \\
\hline Evolution & $\begin{array}{l}\text { The degree to which } \\
\text { evolution is planned to } \\
\text { meet future goals. }\end{array}$ & $\begin{array}{l}\text { No future } \\
\text { changes } \\
\text { considered }\end{array}$ & $\begin{array}{l}\text { Problems and } \\
\text { needs are tracked } \\
\text { but no changes } \\
\text { are intended }\end{array}$ & $\begin{array}{l}\text { It is expected to } \\
\text { do some minor } \\
\text { changes to the } \\
\text { space }\end{array}$ & $\begin{array}{l}\text { High } \\
\text { willingness to } \\
\text { adapt space to } \\
\text { needs and } \\
\text { goals }\end{array}$ & \\
\hline
\end{tabular}

\section{Process of Use}

Criteria Description

Level 1

Level 2

Level 3

Level 4

Ref. 
Published in Journal of Creativity and Innovation Management - Volume 28:82-100 March 2019 DOI: https://doi.org/10.1111/caim.12301

\begin{tabular}{|c|c|c|c|c|c|c|}
\hline $\begin{array}{l}\text { Supporting } \\
\text { Innovation }\end{array}$ & $\begin{array}{l}\text { The stage of the } \\
\text { innovation process in } \\
\text { which the environment } \\
\text { is actually used }\end{array}$ & $\begin{array}{l}\text { Supported } \\
\text { processes are } \\
\text { totally different } \\
\text { from those } \\
\text { intended }\end{array}$ & $\begin{array}{l}\text { Some } \\
\text { processes are } \\
\text { supported }\end{array}$ & $\begin{array}{l}\text { Most of the } \\
\text { intended } \\
\text { processes are } \\
\text { supported }\end{array}$ & $\begin{array}{l}\text { Intended } \\
\text { processes are } \\
\text { totally } \\
\text { supported }\end{array}$ & \multirow{5}{*}{$\begin{array}{l}\text { (Moultrie et } \\
\text { al., 2007) and } \\
\text { author's } \\
\text { experience }\end{array}$} \\
\hline $\begin{array}{l}\text { Supporting } \\
\text { Creativity }\end{array}$ & $\begin{array}{l}\text { The actual way in } \\
\text { which the environment } \\
\text { supports creative } \\
\text { activities }\end{array}$ & $\begin{array}{l}\text { Supported } \\
\text { activities are } \\
\text { totally different } \\
\text { from those } \\
\text { intended }\end{array}$ & $\begin{array}{l}\text { Some } \\
\text { activities are } \\
\text { supported }\end{array}$ & $\begin{array}{l}\text { Most of the } \\
\text { intended } \\
\text { activities are } \\
\text { supported }\end{array}$ & $\begin{array}{l}\text { Intended } \\
\text { activities are } \\
\text { totally } \\
\text { supported }\end{array}$ & \\
\hline $\begin{array}{l}\text { Enabling } \\
\text { teamwork }\end{array}$ & $\begin{array}{l}\text { The actual role of the } \\
\text { space in enabling } \\
\text { physical and virtual } \\
\text { teamwork }\end{array}$ & $\begin{array}{l}\text { It does not } \\
\text { enable } \\
\text { teamwork }\end{array}$ & $\begin{array}{l}\text { Barely } \\
\text { enables } \\
\text { teamwork }\end{array}$ & $\begin{array}{l}\text { Enables } \\
\text { teamwork for } \\
\text { most activities }\end{array}$ & $\begin{array}{l}\text { Totally enables } \\
\text { and enhances } \\
\text { teamwork }\end{array}$ & \\
\hline $\begin{array}{l}\text { Actual users } \\
\& \\
\text { facilitators }\end{array}$ & $\begin{array}{l}\text { The actual users of the } \\
\text { space }\end{array}$ & $\begin{array}{l}\text { Current users } \\
\text { are totally } \\
\text { different than } \\
\text { expected }\end{array}$ & $\begin{array}{l}\text { Some users } \\
\text { match those } \\
\text { intended }\end{array}$ & $\begin{array}{l}\text { Most of the } \\
\text { users are as } \\
\text { intended }\end{array}$ & $\begin{array}{l}\text { The whole } \\
\text { community } \\
\text { matches intent } \\
\text { and culture }\end{array}$ & \\
\hline $\begin{array}{l}\text { Actual } \\
\text { events }\end{array}$ & $\begin{array}{l}\text { The actual type of } \\
\text { events held }\end{array}$ & $\begin{array}{l}\text { The space is } \\
\text { used for } \\
\text { different events } \\
\text { and activities } \\
\text { than intended }\end{array}$ & $\begin{array}{l}\text { Most of the } \\
\text { events are } \\
\text { unintended }\end{array}$ & $\begin{array}{l}\text { Majority of } \\
\text { events match } \\
\text { the initial } \\
\text { intent }\end{array}$ & $\begin{array}{l}\text { Space is used } \\
\text { only for } \\
\text { intended events }\end{array}$ & \\
\hline
\end{tabular}

\section{Innovation Outcomes}

\section{Innovation Outcomes}

Achievement of Strategic Intention

Tangible Results

Intangible Results

Contact author: fosoriob@unal.edu.co 